University of Nebraska - Lincoln

DigitalCommons@University of Nebraska - Lincoln

March 2004

\title{
Characterization of Ground-Water Quality, Upper Republican Natural Resources District, Nebraska, 1998-2001
}

Jill D. Frankforter

Daniele T. Chafin

Follow this and additional works at: https://digitalcommons.unl.edu/usgspubs

Part of the Earth Sciences Commons

Frankforter, Jill D. and Chafin, Daniele T., "Characterization of Ground-Water Quality, Upper Republican Natural Resources District, Nebraska, 1998-2001" (2004). Publications of the US Geological Survey. 7. https://digitalcommons.unl.edu/usgspubs/7

This Article is brought to you for free and open access by the US Geological Survey at DigitalCommons@University of Nebraska - Lincoln. It has been accepted for inclusion in Publications of the US Geological Survey by an authorized administrator of DigitalCommons@University of Nebraska - Lincoln. 
Prepared in cooperation with the Upper Republican Natural Resources District

\section{Characterization of Ground-Water Quality, Upper Republican Natural Resources District, Nebraska, 1998-2001}

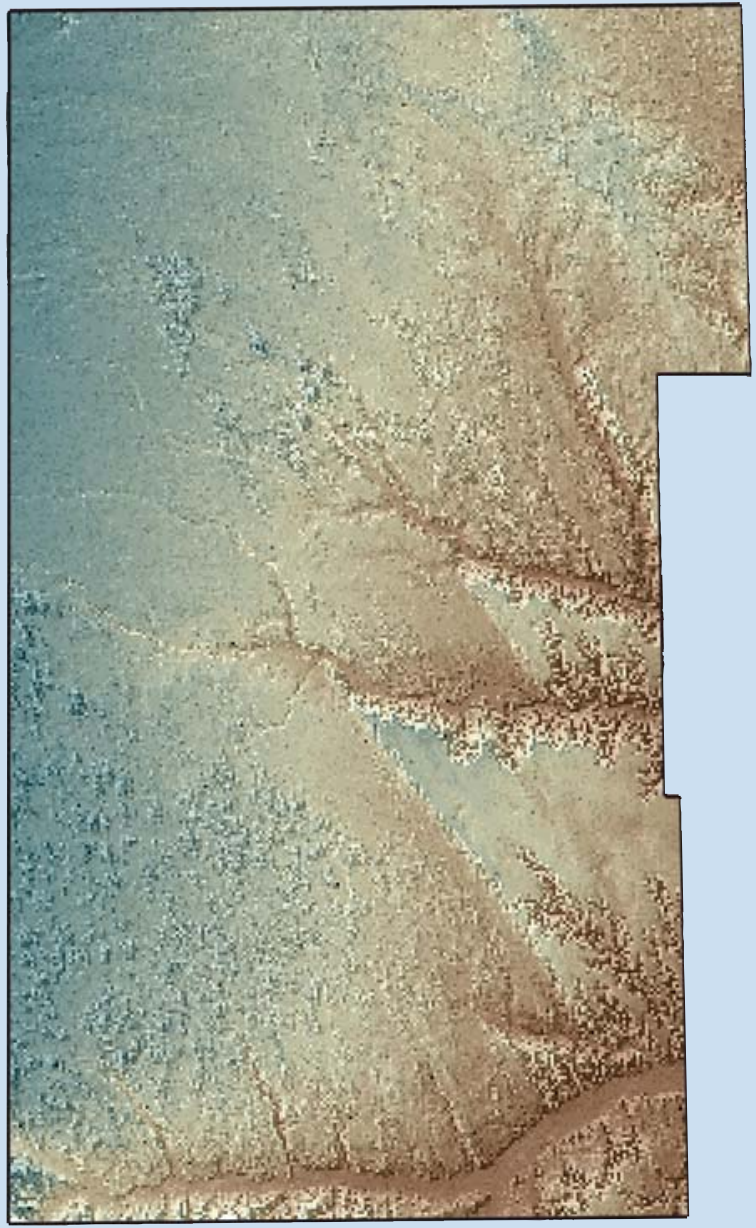

Scientific Investigations Report 2004-5013 


\section{Characterization of Ground-Water Quality, Upper Republican Natural Resources District, Nebraska, 1998-2001}

By Jill D. Frankforter and Daniele T. Chafin

Prepared in cooperation with the Upper Republican Natural Resources District

Scientific Investigations Report 2004-5013 


\title{
U.S. Department of the Interior Gale A. Norton, Secretary
}

\author{
U.S. Geological Survey \\ Charles G. Groat, Director
}

\section{U.S. Geological Survey, Reston, Virginia: 2004}

For sale by U.S. Geological Survey, Information Services

Box 25286, Denver Federal Center

Denver, CO 80225

For more information about the USGS and its products:

Telephone: 1-888-ASK-USGS

World Wide Web: http://www.usgs.gov/

Any use of trade, product, or firm names in this publication is for descriptive purposes only and does not imply endorsement by the U.S. Government.

Although this report is in the public domain, permission must be secured from the individual copyright owners to reproduce any copyrighted materials contained within this report.

Suggested citation:

Frankforter, J.D., and Chafin, D.T., 2004, Characterization of ground-water quality, Upper Republican Natural Resources District, Nebraska, 1998-2001: U.S. Geological Survey Scientific Investigations Report 2004-5013, 24 p. 


\section{Contents}

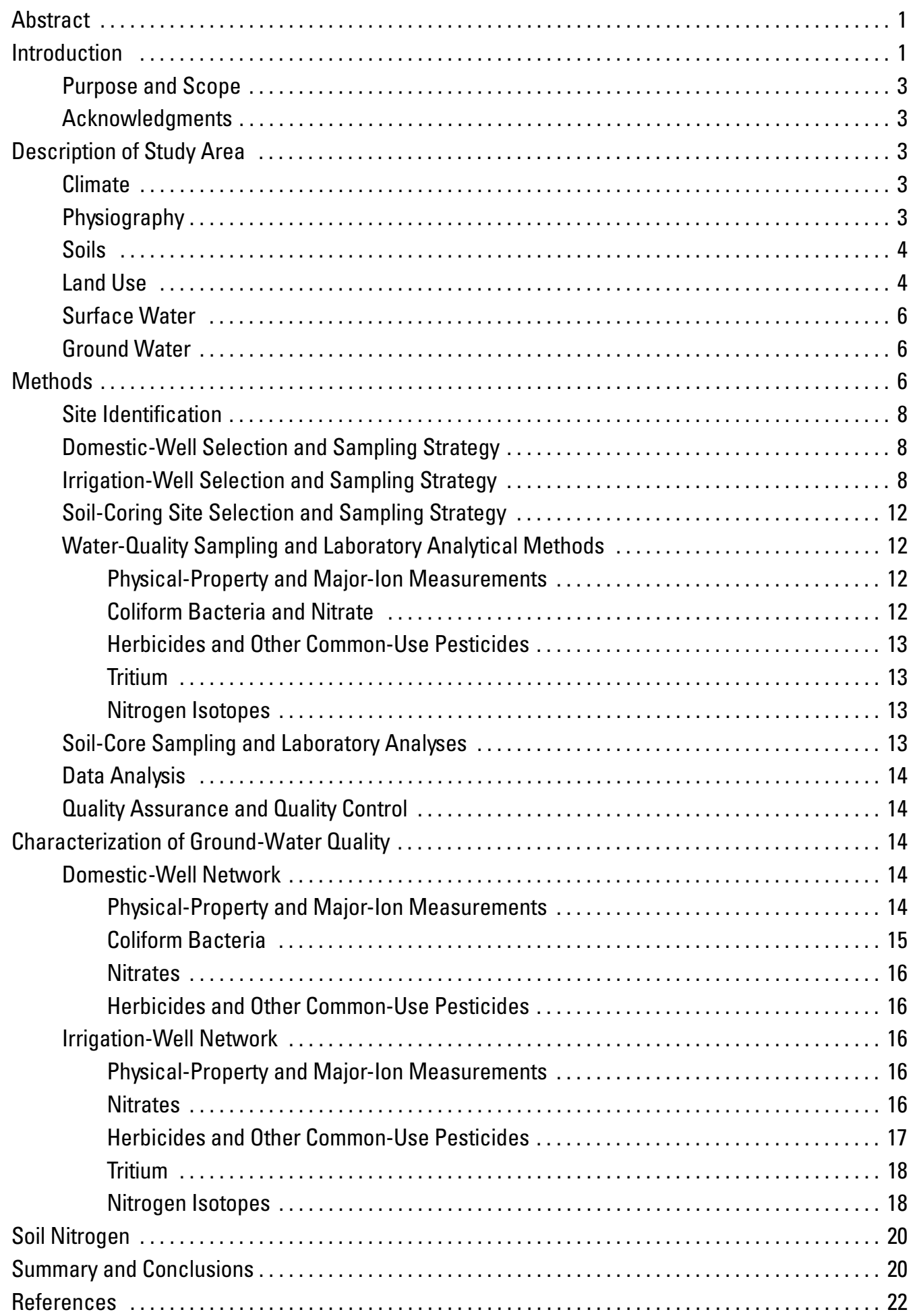




\section{Figures}

1. Map showing location of study area and land use, Upper Republican Natural

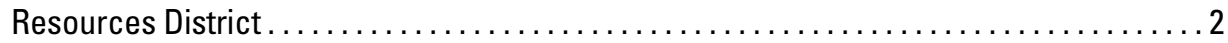

2. Map showing soil types and locations of soil-sampling sites, Upper Republican Natural Resources District ...................................... 5

3. Map showing configuration of the water table, Upper Republican Natural

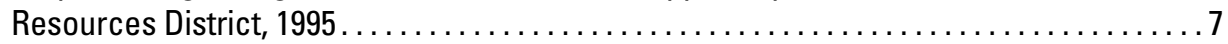

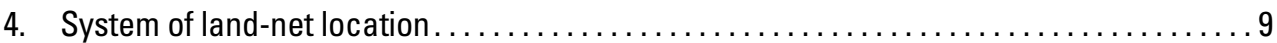

5. Map showing nitrate concentration in ground water from selected domestic wells, Upper Republican Natural Resources District, 1998-2001 . ................ 10

6. Map showing nitrate concentration in ground water from selected irrigation wells, Upper Republican Natural Resources District, 1998-2000 . ................ 11

7. Trilinear diagram showing water types for samples from selected domestic wells, Upper Republican Natural Resources District, $2001 \ldots \ldots \ldots \ldots \ldots \ldots \ldots \ldots 15$

8. Trilinear diagram showing water types for samples from selected irrigation wells, Upper Republican Natural Resources District, 1998-2000. .

9. Map showing tritium and nitrogen-isotope values in water samples from selected irrigation wells, Upper Republican Natural Resources District, 2000.

10. Graphs showing nitrogen content in soil-core samples by depth, land use, and soil type, Upper Republican Natural Resources District, 1998-99 ...

\section{Tables}

1. Types and hydrologic characteristics of soils, Upper Republican Natural

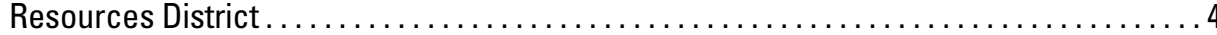

2. Water-quality data for selected domestic wells, Upper Republican Natural Resources District, 1998-2001. .

3. Water-quality data for selected irrigation wells, Upper Republican Natural Resources District, 1998-2000.

4. Unsaturated soil-coring site descriptions and nitrogen content of soil samples, Upper Republican Natural Resources District, 1998-99.

5. Summary statistics for ground-water quality constituents in samples from selected domestic wells, Upper Republican Natural Resources District, Nebraska, 1998 to 2001

6. Summary statistics for ground-water quality constituents in samples from selected irrigation wells, Upper Republican Natural Resources District, Nebraska, 1998 to 2000

7. Total and fecal coliform bacteria data from selected domestic wells, Upper Republican Natural Resources District, 1998 and 1999 


\section{Conversion Factors and Datum}

\begin{tabular}{|c|c|c|}
\hline Multiply & By & To obtain \\
\hline \multicolumn{3}{|c|}{ Length } \\
\hline inch (in.) & 2.54 & centimeter \\
\hline foot $(\mathrm{ft})$ & 0.3048 & meter \\
\hline mile (mi) & 1.609 & kilometer \\
\hline \multicolumn{3}{|c|}{ Area } \\
\hline acre & 0.004047 & square kilometer \\
\hline square mile $\left(\mathrm{mi}^{2}\right)$ & 2.590 & square kilometer \\
\hline \multicolumn{3}{|c|}{ Volume } \\
\hline acre-foot (acre-ft) & 1,233 & cubic meter \\
\hline \multicolumn{3}{|c|}{ Flow rate } \\
\hline gallon per minute (gal/min) & 0.06309 & liter per second \\
\hline inch per hour (in/h) & 0.0254 & meter per hour \\
\hline inch per year (in/yr) & 25.4 & millimeter per year \\
\hline
\end{tabular}

foot per mile (ft/mi) $\quad 0.1894 \quad$ meter per kilometer

Temperature in degrees Celsius $\left({ }^{\circ} \mathrm{C}\right)$ may be converted to degrees Fahrenheit $\left({ }^{\circ} \mathrm{F}\right)$ as follows:

${ }^{\circ} \mathrm{F}=\left(1.8 \mathrm{x}^{\circ} \mathrm{C}\right)+32$

Temperature in degrees Fahrenheit $\left({ }^{\circ} \mathrm{F}\right)$ may be converted to degrees Celsius $\left({ }^{\circ} \mathrm{C}\right)$ as follows:

${ }^{\circ} \mathrm{C}=\left({ }^{\circ} \mathrm{F}-32\right) / 1.8$

Vertical coordinate information is referenced to the North American Vertical Datum of 1988 (NAVD 88); horizontal coordinate information is referenced to the North American Datum of 1927 (NAD 27).

Specific conductance is given in microsiemens per centimeter at 25 degrees Celsius $(\mu \mathrm{S} / \mathrm{cm})$. Concentrations of chemical constituents in water are given in milligrams per liter $(\mathrm{mg} / \mathrm{L})$ and micrograms per liter $(\mu \mathrm{g} / \mathrm{L})$. Concentrations of nitrogen in soil are given in milligrams per kilogram $(\mathrm{mg} / \mathrm{kg})$ or pounds per acre (lb/acre). 


\title{
Characterization of Ground-Water Quality, Upper Republican Natural Resources District, Nebraska, 1998-2001
}

\author{
By Jill D. Frankforter and Daniele T. Chafin
}

\section{Abstract}

Nearly all rural inhabitants and livestock in the Upper Republican Natural Resources District (URNRD) in southwestern Nebraska use ground water that can be affected by elevated nitrate concentrations. The development of ground-water irrigation in this area has increased the vulnerability of ground water to the introduction of fertilizers and other agricultural chemicals. In 1998, the U.S. Geological Survey, in cooperation with the Upper Republican Natural Resources District, began a study to characterize the quality of ground water in the Upper Republican Natural Resources District area with respect to physical properties and concentrations of major ions, coliform bacteria, nitrate, and pesticides, and to assess the presence of nitrogen concentrations in the unsaturated zone. At selected well sites, the ground-water characterization also included tritium and nitrogen-isotope analyses to provide information about the approximate age of the ground water and potential sources of nitrogen detected in ground-water samples, respectively.

In 1998, ground-water samples were collected from 101 randomly selected domestic-well sites. Of the 101 samples collected, 26 tested positive for total coliform bacteria, exceeding the U.S. Environmental Protection Agency's Maximum Contaminant Level (MCL) of zero colonies. In 1999, groundwater samples were collected from 31 of the 101 well sites, and 16 tested positive for coliform bacteria.

Nitrates were detected in ground water from all domesticwell samples and from all but four of the irrigation-well samples collected from 1998 to 2001. Eight percent of the domestic-well samples and 3 percent of the irrigation-well samples had nitrate concentrations exceeding the U.S. Environmental Protection Agency's MCL for drinking water of 10 milligrams per liter. Areas with nitrate concentrations exceeding 6 milligrams per liter, the URNRD's ground-water management-plan action level, were found predominantly in north-central Chase, western and south-central Dundy, and south-central Perkins Counties. Generally, these concentrations were detected in samples from wells located in upland areas with permeable soils and a high percentage of cropland.

In 1999, 31 of the ground-water samples collected from irrigation wells were analyzed for pesticides, and 14 samples (45 percent) had detectable concentrations of at least one pesticide compound. In 2000, all of the 23 irrigation-well samples analyzed had one or more pesticides present at detectable concentrations. In 2001, 12 of 26 domestic-well samples (46 percent) had detectable concentrations. Although the analytical method used during the study was changed to increase the number of pesticides included in the analyses, the pesticides detected in the ground-water samples from domestic and irrigation wells were limited to the commonly used herbicide compounds acetochlor, alachlor, atrazine, metolachlor, prometon, propachlor, propazine, trifluralin, and the atrazine degradation product deethylatrazine. Of the compounds detected, only atrazine (3.0 micrograms per liter) and alachlor (2.0 micrograms per liter) have MCLs established by the U.S. Environmental Protection Agency. None of the ground-water samples from the URNRD study area had concentrations that exceeded either MCL.

Tritium age-dating analyses indicate water from about one-third of the sites entered the ground-water system prior to 1952. Because the increase in agricultural practices occurred during the 1950s and 1960s, it can be assumed that this water was not influenced by agricultural practices. Nitrogen-isotope speciation analyses for samples from three irrigation wells indicated that the source of nitrates in the ground water probably is synthetic fertilizer; however, the source at most irrigation wells probably is either naturally occurring or a mixture of water from various anthropogenic sources (such as synthetic fertilizer and animal waste).

\section{Introduction}

In the 1950s, about 50 percent of land in the Upper Republican Natural Resources District (URNRD) was used for crop production. Since the 1950s, the percentage of cropland has remained relatively stable (fig. 1); however, the type of crops grown in the URNRD area has shifted from wheat and sorghum to predominantly corn. This shift in crop type began in the 1960 s, with the widespread development of ground-water irrigation practices. By 1995, more than 25 percent of the surface area in the URNRD was irrigated with ground water (Nebraska Department of Natural Resources, 2002), and as of September 2002 , about 3,200 active irrigation wells were registered in the three-county area of the URNRD (Heather Francis, Upper Republican Natural Resources District, written commun., 2002). 


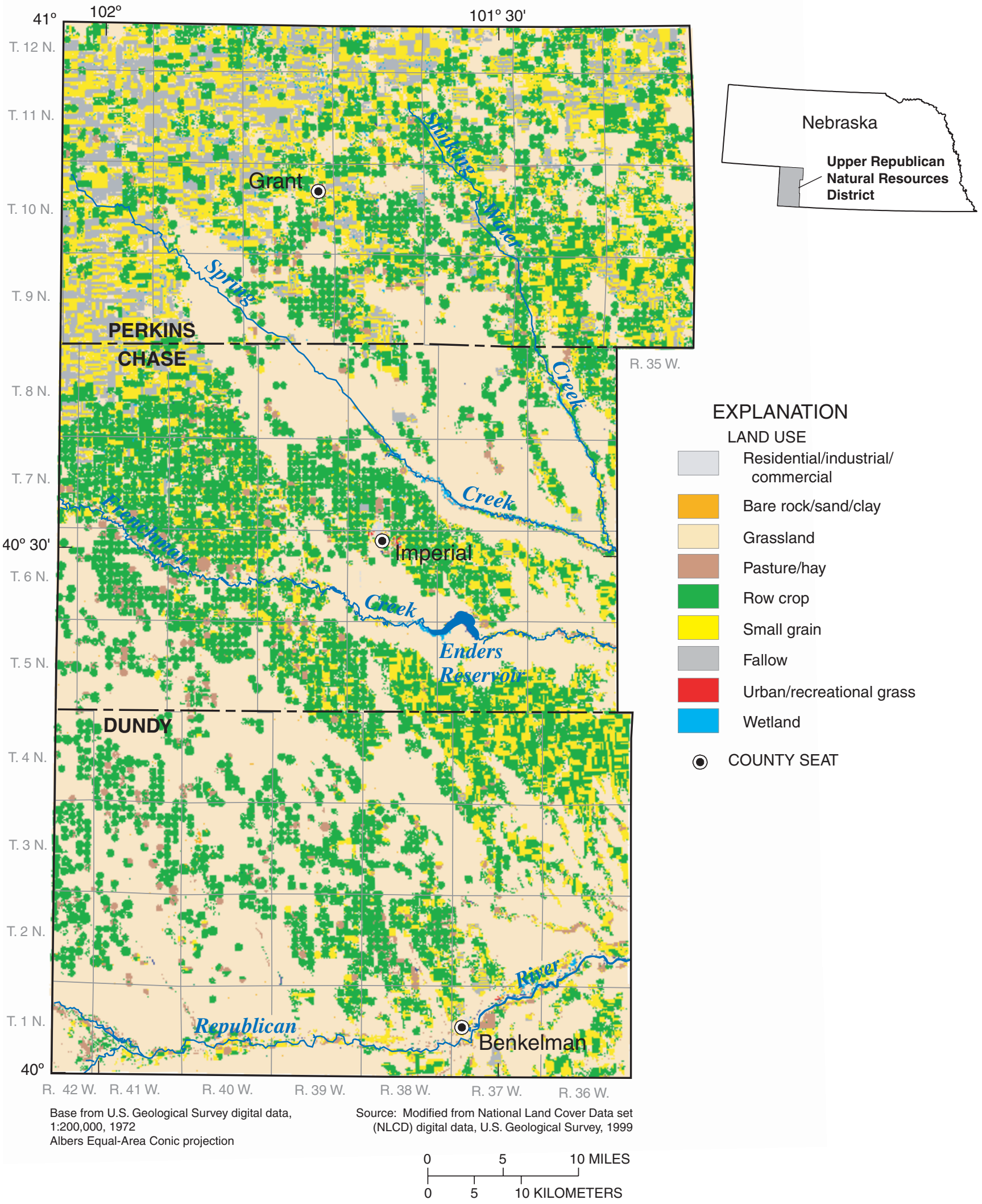

Figure 1. Location of study area and land use, Upper Republican Natural Resources District. 
The development of ground-water irrigation and associated use of fertilizers and other agricultural chemicals to sustain high crop yields have increased the potential for these compounds to leach into the ground water. As a result, nearly all inhabitants and livestock in the URNRD area use ground water that is vulnerable to these agricultural chemicals. Area residents and water-resources managers are particularly concerned that ground-water nitrate concentrations in some locations in the URNRD have exceeded the U.S. Environmental Protection Agency's (USEPA) Maximum Contaminant Level (MCL) of 10 milligrams per liter $(\mathrm{mg} / \mathrm{L})$ for nitrate (U.S. Environmental Protection Agency, 2002).

In 1998, the U.S. Geological Survey (USGS), in cooperation with the URNRD, began a 4-year study to characterize the spatial and temporal variability of ground-water quality in the area with respect to physical properties, major ions, coliform bacteria, concentrations of nitrite plus nitrate (hereinafter referred to as nitrate because nitrite concentrations are negligible), and pesticides using networks of irrigation and domestic wells that were selected to be statistically representative of ground-water quality in the principal aquifers in the area. A small number of samples from the irrigation-well network also were analyzed for tritium and nitrogen isotopes to provide information about the approximate age of the ground water and potential sources of nitrogen detected in ground-water samples. Additionally, soil samples collected from the shallow unsaturated zone were analyzed for nitrate and ammonia to assess nutrient uptake efficiencies in areas with varied land uses and soil types, which could relate to differences in ground-water quality. The study objectives were accomplished by: (1) establishing networks of domestic and registered irrigation wells from which to collect ground-water samples; (2) collecting and analyzing ground-water samples from those wells; and (3) collecting and analyzing samples from soil cores from the shallow unsaturated zone.

\section{Purpose and Scope}

The purpose of this report is to present ground-water quality data collected during 1998-2001 in the URNRD and characterize ground-water quality. Specifically, this report describes the analytical results for physical properties, major ions, coliform bacteria, nitrate, and pesticides in ground-water samples, tritium and nitrogen isotopes in a small number of ground-water samples, and nitrogen concentrations in soil samples. This report also describes the methods used to select wells and soil-sampling sites, and to collect and analyze ground-water and soil samples.

\section{Acknowledgments}

The authors thank Heather Francis of the Upper Republican Natural Resources District for her continuous technical assistance during the study. The authors also thank the land- owners who allowed study unit personnel access to the sampling sites during this study.

\section{Description of Study Area}

The study area consists of Perkins, Chase, and Dundy Counties in southwestern Nebraska (fig. 1) and covers about $2,700 \mathrm{mi}^{2}$. Elevations range from about $2,840 \mathrm{ft}$ above NAVD 88 near the Republican River in southeast Dundy County to about $3,730 \mathrm{ft}$ above NAVD 88 in central Chase County. The land surface in the study area generally slopes downward to the east at about $10 \mathrm{ft} / \mathrm{mi}$.

\section{Climate}

The climate of the URNRD varies between dominantly semiarid to subhumid conditions, and is typical of a continental climate with wide variations in temperature, including frequently cold winters and hot summers. The average annual precipitation (1961-90) ranges from 16 to $20 \mathrm{in} / \mathrm{yr}$, and during this study ranged from $20 \mathrm{in.} \mathrm{in} \mathrm{1998,} \mathrm{to} 18 \mathrm{in.}$ in 2001 (Nebraska Climate Office, 2003). Thunderstorms occur often between the months of April and July. January generally is the coldest month of the year, with temperatures typically ranging from about 11 to $39^{\circ} \mathrm{F}$ (Nebraska Climate Office, 2003). July generally is the hottest month of the year, with temperatures typically ranging from 60 to $90^{\circ} \mathrm{F}$.

\section{Physiography}

The study area lies in the High Plains Section of the Great Plains Physiographic Province (Fenneman, 1931). The following principal physiographic features are present in the URNRD (Lappala, 1978):

1. Loess plains and tablelands occur mainly in Perkins County, western and southeastern Chase County, and northeastern Dundy County. Surface drainage is evident, slopes are less than 7 percent, and drainages consist of broad, grassy swales where rapid surface runoff is rare; rolling uplands occur primarily in northeastern Perkins County. Flat areas in this category contain numerous small closed depressions, which serve as local recharge basins where bottom sediments are sufficiently permeable. Surface runoff in flat areas is more rapid than in loess plains and tablelands, and erosional features include broad valleys, swales, and stairstep slumping on valley sides where they are underlain by loess.

2. Sandhills and interdune valleys occur in all three counties, the largest of which are in western Dundy and southwestern Chase Counties. Local relief between valleys and dune crests and saddles is about of 50 to $150 \mathrm{ft}$, slopes range from 0 to 50 percent, and surface 
drainage generally is poorly defined with closed basins or interior drainage being common. Many interdune valleys contain lakes and swamps maintained by ground-water discharge.

3. Dissected plains and uplands occur in eastern Chase and Dundy Counties. Slopes locally exceed 50 percent, surface drainage is well defined, surface runoff is rapid, and erosion potential is great when precipitation is intense.

4. Bottom lands occur along major streams, usually found along the alluvial valleys of the Republican River, and Frenchman, Spring, and Stinking Water Creeks. Slopes are less than 5 percent, and surface drainage is altered locally because of changing surface flow regimes.

\section{Soils}

The surface soils in the study area generally vary with topographic position in landscape from bottomland, upland, and dune sand deposits, with each soil series grouped by hydrologic characteristics that include permeability, water capacity, and slope (table 1). Bottom lands and terraces along the valley floors comprise only 5 percent of the study area. Soils from bottom lands and terraces (fig. 2) generally are fine sandy loams to silt loams with permeabilities of 0.6 to $20 \mathrm{in} / \mathrm{hr}$ and gentle slopes of 0 to 7 percent (Soil and Conservation Service, 1963, 1982, and 1991).

Hydrologic characteristics of upland soils tend to vary widely reflecting different parent material. Textures vary from fine sand to sandy loam to silty clay loam (table 1) (Peckenpaugh and others, 1995). Permeabilities of upland soils are generally low but can be greater than $20 \mathrm{in} / \mathrm{hr}$. Slopes on uplands range from 0 to 60 percent.

\section{Land Use}

Land in the URNRD study area is used predominantly for agricultural purposes (fig. 1) consisting of irrigated and dryland cultivation and grassland. Topography and soil type generally determine the use of the land. Soil types derived from sand dunes or with steep slopes usually are left as uncultivated grassland, and are covered in natural vegetation. Soil types with less sandy textures, or with relatively gentle slopes, are well suited for irrigated crops. Approximately 80 percent of the crops in the study area are irrigated by center-pivot irrigation systems (Johnson, 2001).

Most inhabitants of the URNRD area live in a rural setting. In 2000, the population of the URNRD was 9,560 people, with an average population density of 3.54 people per square mile (U.S. Census Bureau, 2002). The 2000 population was 4,068 people in Chase County, 2,292 in Dundy County, and 3,200 in Perkins County (U.S. Census Bureau, 2002).

Table 1. Types and hydrologic characteristics of soils, Upper Republican Natural Resources District.

[Soil Conservation Service, 1963, 1982, and 1991; in/hr, inches per hour; >, greater than]

\begin{tabular}{|c|c|c|c|c|c|}
\hline $\begin{array}{l}\text { Soil series and } \\
\text { associations }\end{array}$ & $\begin{array}{l}\text { Topographic } \\
\text { position }\end{array}$ & Texture & $\begin{array}{l}\text { Permeability } \\
\text { (in/hr) }\end{array}$ & $\begin{array}{c}\text { Slope } \\
\text { (percent) }\end{array}$ & $\begin{array}{c}\text { Available water } \\
\text { capacity } \\
\text { (in/hr) }\end{array}$ \\
\hline Bankard-Glenberg-Las Animas & Bottom lands & Loamy find sand & 6 to 20 & 0 to 2 & 0.05 to 0.08 \\
\hline Bridget-McCook-Duroc & $\begin{array}{l}\text { Bottom lands } \\
\text { and terraces }\end{array}$ & Sandy loam to silt loam & 0.6 to 2.0 & 0 to 7 & 0.17 to 0.24 \\
\hline Dix-Altvan-Keith & Uplands & $\begin{array}{l}\text { Very gravelly sandy loam to } \\
\text { silt loam }\end{array}$ & 0.6 to $>20$ & 6 to 30 & 0.02 to 0.22 \\
\hline Elsmere-Dailey-Sarben & Uplands & Loamy sand & 6.0 to 20 & 0 to 5 & 0.04 to 0.12 \\
\hline Fluvaquents-Alda-Bankard & Bottom lands & Loamy sand to fine sand & 0.6 to 2.0 & 0 to 2 & 0.16 to 0.24 \\
\hline Kuma Series & Uplands & Silt loam to silty clay loam & 0.6 to 2.0 & 0 to 7 & 0.18 to 0.21 \\
\hline Valent-Valentine Series & Uplands & Fine sand to loamy sand & 6 to $>20$ & 0 to 60 & 0.03 to 0.12 \\
\hline Wann-Gibbon-Leshara & Bottom lands & Fine sandy loam to silt loam & 0.6 to 6.0 & 0 to 2 & 0.09 to 0.23 \\
\hline Woodly-Jayem-Ascalon & $\begin{array}{l}\text { Bottom lands } \\
\text { and terraces }\end{array}$ & Fine sand to sandy loam & 0.6 to 6.0 & 0 to 3 & 0.06 to 0.19 \\
\hline
\end{tabular}




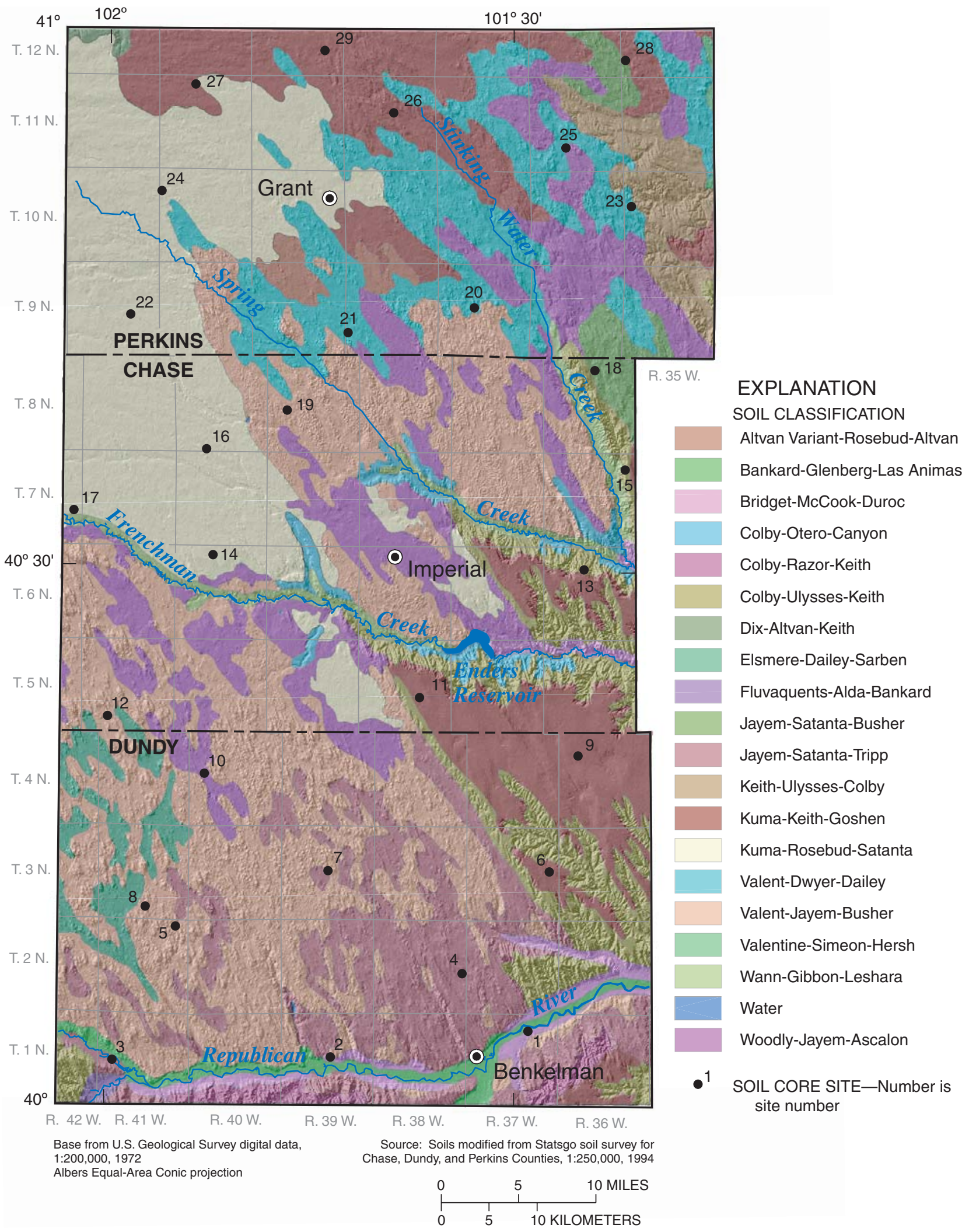

Figure 2. Soil types and locations of soil-sampling sites, Upper Republican Natural Resources District. 


\section{Characterization of Ground-Water Quality, Upper Republican Natural Resources District, Nebraska, 1998-2001}

\section{Surface Water}

Surface water in the study area consists of rivers, streams, and a reservoir (fig. 1). The main surface-water features include the Republican River and its tributaries, and Frenchman, Spring, and Stinking Water Creeks. Enders Reservoir, which is located in Chase County, has an average surface area of 1,242 acres and is used for storing water from Frenchman Creek for surface-water irrigation. Water is released from Enders Reservoir into Frenchman Creek during the irrigation season and flows out of the study area (Peckenpaugh and others, 1995).

The interaction of these surface-water components with each other, and with the ground-water system, is complex. A recent study of surface- and ground-water interactions on major tributaries to the Republican River (Steele, 1999) found the interactions to be highly variable, with the hydraulic connection changing throughout the year. Some reaches of the Republican River are gaining reaches, at least when ground-water pumpage for irrigation does not influence the system (Steele, 1998). On these reaches during periods when storm runoff is minimal, streamflow increases as ground water discharges into the stream. The fraction of ground-water discharge to total streamflow becomes proportionally smaller as surface-water flow increases, and at maximum flow, some surface flow is lost into bank storage (Steele, 1999). Historically, Frenchman Creek also was a gaining, perennial stream (Bureau of Reclamation, 1974). The two reaches of Frenchman Creek included in the Republican River study (Steele, 1999) were determined to be either losing water to, or disconnected from, the ground-water system. The reduction of ground-water discharge in the area may be the result of increased ground-water pumpage for irrigation on both sides of Frenchman, Spring, and Stinking Water Creeks (Lappala, 1976). By 1975, flow in Spring and Stinking Water Creeks had been depleted by about 18 percent from quantities measured in 1967, and flow in Frenchman Creek had been depleted by about 19 percent (Lappala, 1976).

\section{Ground Water}

The study area has a complex ground-water system, where the type and thickness of the formations largely control the movement of water. Generally, the uppermost, consolidated bedrock unit in the study area is the Pierre Shale of Cretaceous age (Peckenpaugh and others, 1995). The Pierre Shale consists mostly of blue, ochre, or black-colored shale and clay, and is relatively impermeable, forming the lower boundary of the saturated thickness of near-surface aquifers. In parts of Chase and Perkins Counties, the White River Group of Tertiary age overlies the Pierre Shale (Peckenpaugh and others, 1995). The White River Group consists of the lower Chadron Formation and the upper Brule Formation. The Chadron Formation generally consists of olive-green to brick-red, silty to sandy clay and claystone (Cardwell and Jenkins, 1963). The Brule Formation consists of buff to olive-green clayey silt and siltstone. Where present, these units are overlain by the Ogallala Group of Tertiary age. Where the White River Group is absent, the Ogallala Group overlies the Pierre Shale (Peckenpaugh and others, 1995).

The High Plains aquifer and alluvial aquifers adjacent to the main surface-water features are the primary aquifers in the study area. The High Plains aquifer consists of the Ogallala Group and underlies most of the study area and yields most of the ground water to wells. It consists of loosely cemented sandstone, caliche, sand, gravel, and volcanic ash. The depth to water and saturated thickness of the High Plains aquifer vary greatly across the URNRD study area. Depths to ground water range from about $50 \mathrm{ft}$ in western Dundy County to more than $290 \mathrm{ft}$ in the uplands of southeastern Chase County (Heimes and others, 1987), with semi-artesian conditions occurring in parts of Chase and Perkins Counties. The saturated thickness ranges from about 25 to $50 \mathrm{ft}$ in the southern part of the study area to more than $400 \mathrm{ft}$ in the northeast (Heimes and others, 1987). The alluvial aquifers are thin (generally less than $50 \mathrm{ft}$ thick) unconsolidated sand and gravel deposits of Quaternary age. Typically, the alluvial aquifers fill the valleys and serve as important aquifers where present and where sufficient saturated thickness exists. The depth to water in the alluvial aquifer systems associated with Frenchman, Spring, and Stinking Water Creeks, and the Republican River can be as little as $5 \mathrm{ft}$ below land surface.

The first irrigation wells in the area were completed in 1913 in Chase County (Peckenpaugh and others, 1995). The number of irrigation wells increased rapidly through the 1970s, before stabilizing during the 1980s. In 1995, water use for irrigation was 198,900 acre-ft in Chase County, 115,800 acre-ft in Dundy County, and 156,400 acre-ft in Perkins County (Nebraska Department of Natural Resources, 2002). Increased use of ground water for irrigation has substantially decreased water levels and rates of water seepage from aquifers into nearby streams, with areas of greatest decline in water levels corresponding to areas with the greatest density of irrigation wells (Peckenpaugh and others, 1995).

The water-table map for the URNRD (fig. 3) shows that near-surface ground water generally flows eastward. The watertable gradient ranges from about $8.5 \mathrm{ft} / \mathrm{mi}$ in Perkins County to about $17.5 \mathrm{ft} / \mathrm{mi}$ in southern Chase County. Water-table contours along the Republican River show strong gaining conditions for that river.

\section{Methods}

This section presents site selection criteria for wells included in the domestic- and irrigation-well networks and for the soil-coring sites, specific sampling techniques used to collect ground-water and soil samples, and quality-control measures taken to assess data reliability and representativeness. 


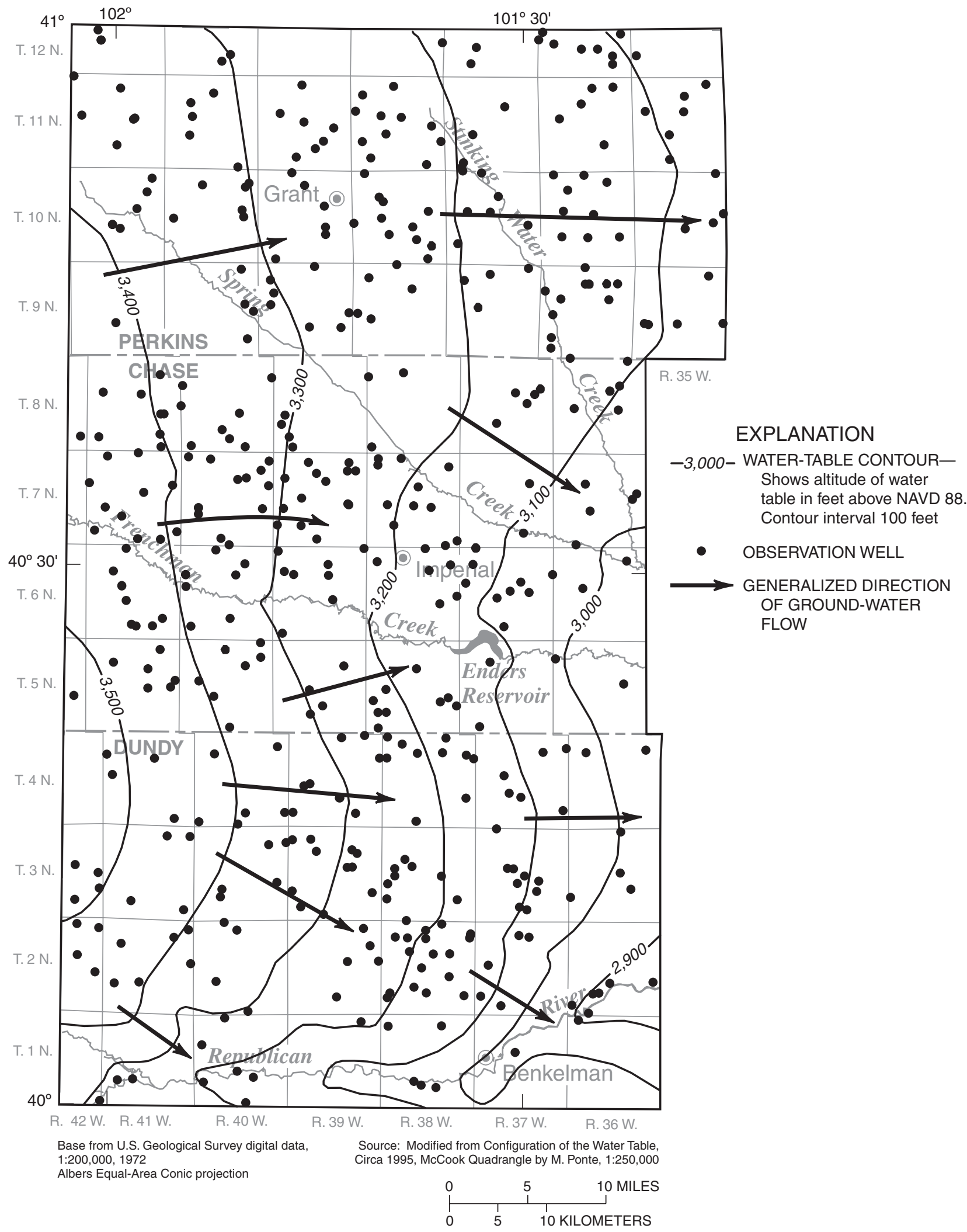

Figure 3. Configuration of the water table, Upper Republican Natural Resources District, 1995. 


\section{Characterization of Ground-Water Quality, Upper Republican Natural Resources District, Nebraska, 1998-2001}

\section{Site Identification}

This report uses three different methods for identification or location of water wells. The first method, the USGS station identification number, assigns a unique number (such as 403036101220901) to each site (tables 2 and 3, on CD-ROM at back of this report). The USGS ground-water station identification number is a 15-character number derived from the international system of latitude and longitude. Although the station identification number usually is derived originally from the site location (latitude and longitude), the number is an identifier and not a locator (Mathey, 1990).

Location of water wells also is based on the land-net subdivisions in the Bureau of Land Management's (BLM) survey of Nebraska (fig. 4; tables 2 and 3). The number preceding $\mathrm{N}$ (north) indicates the township or tier, the number preceding $\mathrm{W}$ (west) indicates the range, and the number preceding the terminal letters indicates the section in which the well is located (2N36W21DCCD). The terminal letters designated A, B, C, and $\mathrm{D}$, denote the quarter section, the quarter-quarter section, the quarter-quarter-quarter section, and the quarter-quarterquarter-quarter section. The designation is given in a counterclockwise direction beginning with " $\mathrm{A}$ " in the northeast corner of each subdivision. An "O" following the terminal letter indicates the well is in the center of the subdivision. A serial number following the last letter is used to distinguish between wells in the same $21 / 2$-acre tract.

The third method, the well registration number, is used to identify the registered irrigation wells in this report (table 3). Well registration numbers, such as G-031164, are assigned by the Nebraska Department of Natural Resources.

\section{Domestic-Well Selection and Sampling Strategy}

The network of domestic wells was established to evaluate baseline water quality of ground-water resources used for human consumption. Because few domestic wells in the area are registered with the State of Nebraska, it was not possible to select sufficient statistically representative sites for the domestic-well network from among the registered wells. To ensure that the wells selected for this study were statistically representative, domestic wells that were not registered with the State of Nebraska were included. Drillers' or other construction logs for these wells generally were not available; therefore, the aquifer that was sampled could not be determined. Water samples likely were from the High Plains aquifer or from an alluvial aquifer.

Domestic wells were selected using a stratified, random selection process with an areal spacing factor. Initially, a singular list of 100 townships, ranges, and sections was generated. If a selected section was within 1 mi of a previously selected site, a new location was selected randomly. The list of selected sections was given to URNRD personnel, who identified the locations of domestic wells within each section. If several domestic wells were located in a given section, a single well was selected randomly. Based on conversations with the well owner and observations prior to initial sampling, suitable network wells were identified based on the following criteria: (1) the domestic well was actively being used as a household drinking-water supply; (2) a water sample could be collected prior to exposure to any type of water treatment or storage (such as filtration or residence in a pressure tank or cistern); and (3) onsite observations determined that point-source contamination from septic tanks, feedlots, municipal dumps, and industry was not a concern. If a well was found to be unsuitable, an alternate well was selected randomly within a 4-mi radius of the initial site.

A network of 101 domestic wells was established and sampled in 1998 (fig. 5; table 2). Samples collected from these wells were analyzed for nitrate and coliform bacteria (total and fecal). Although additional sampling of domestic wells was not proposed initially, 31 wells were sampled again in August 1999 (table 2). The wells were resampled because either the nitrate concentration detected in the 1998 sample was near, or exceeded, the URNRD's ground-water management-plan action level of $6 \mathrm{mg} / \mathrm{L}$, or because the 1998 bacteria analysis indicated the presence of coliform bacteria. In September 2001, 24 of the domestic wells were sampled again, along with 2 additional wells, to evaluate the ground water for the presence of pesticides and to collect major-ion data (table 2). The wells sampled in 2001 also were selected for additional sampling because they had, or were in areas of, the highest concentrations of nitrate detected in the ground water.

\section{Irrigation-Well Selection and Sampling Strategy}

The network of irrigation wells was established to evaluate baseline ground-water quality characteristics in wells with an even spatial distribution throughout the URNRD and documented well-construction information. The registered irrigation wells were identified using a stratified, random selection process with an areal spacing factor. Initially, 300 irrigation wells were selected randomly from a list of registered wells. If two wells were located within $1 \mathrm{mi}$ of each other, another well location was randomly generated. Once selected, wells were evaluated to determine acceptability for sampling. A well was acceptable if (1) a completed drillers' log and well-construction information were available; (2) it was screened in a single hydrogeologic unit; (3) the well owner granted permission to sample. The acceptability of the well was evaluated further by onsite observations of potential point-source contamination by septic tanks, feedlots, municipal dumps, and industry, and for appropriate sampling points (see the 'Water-Quality Sampling and Laboratory Analytical Methods' section of this report). If a well did not meet selection criteria, an alternate registered well was selected in the same township and range, and screened for suitability. Analytical results from wells sampled as part of another sampling effort in the study area (Stanton, 2000) were included in this data analysis. As a result, a total of 368 registered irrigation wells were included in the network in 1998 (fig. 6 and table 3). Samples from all of the wells were analyzed for nitrate concentrations, and 114 samples also were analyzed for major ions. 


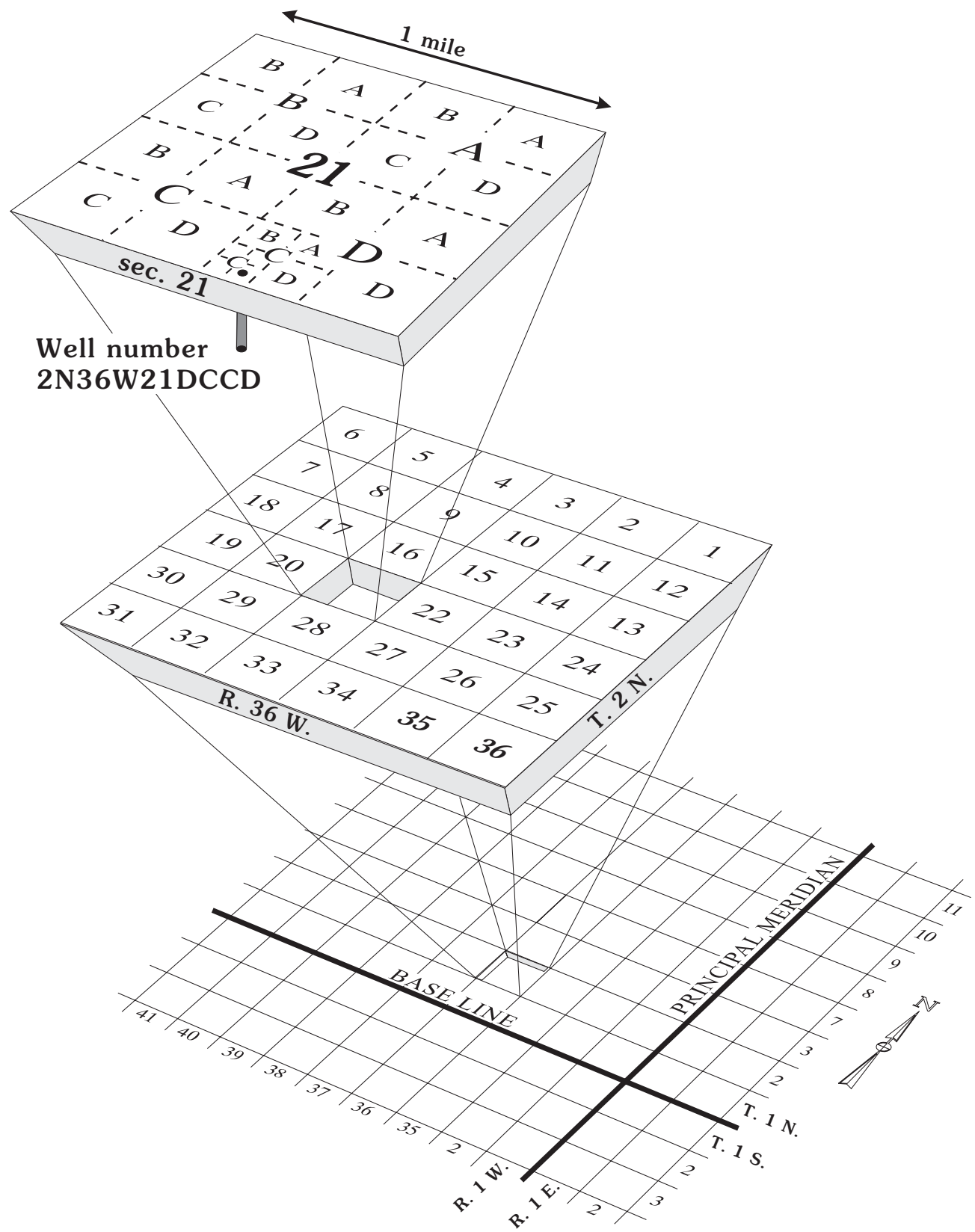

Figure 4. System of land-net location. 


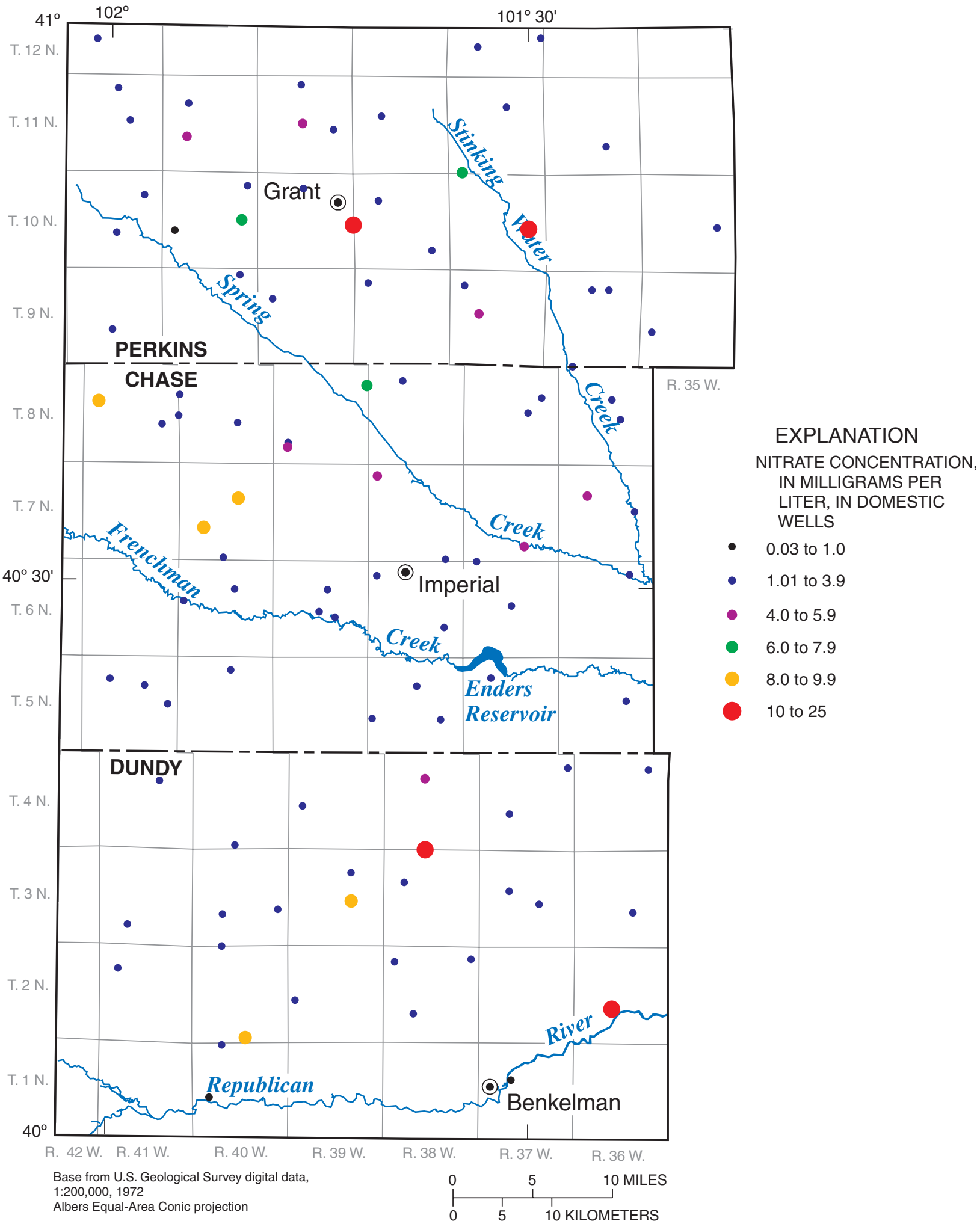

Figure 5. Nitrate concentrations in ground water from selected domestic wells, Upper Republican Natural Resources District, 1998-2001. 


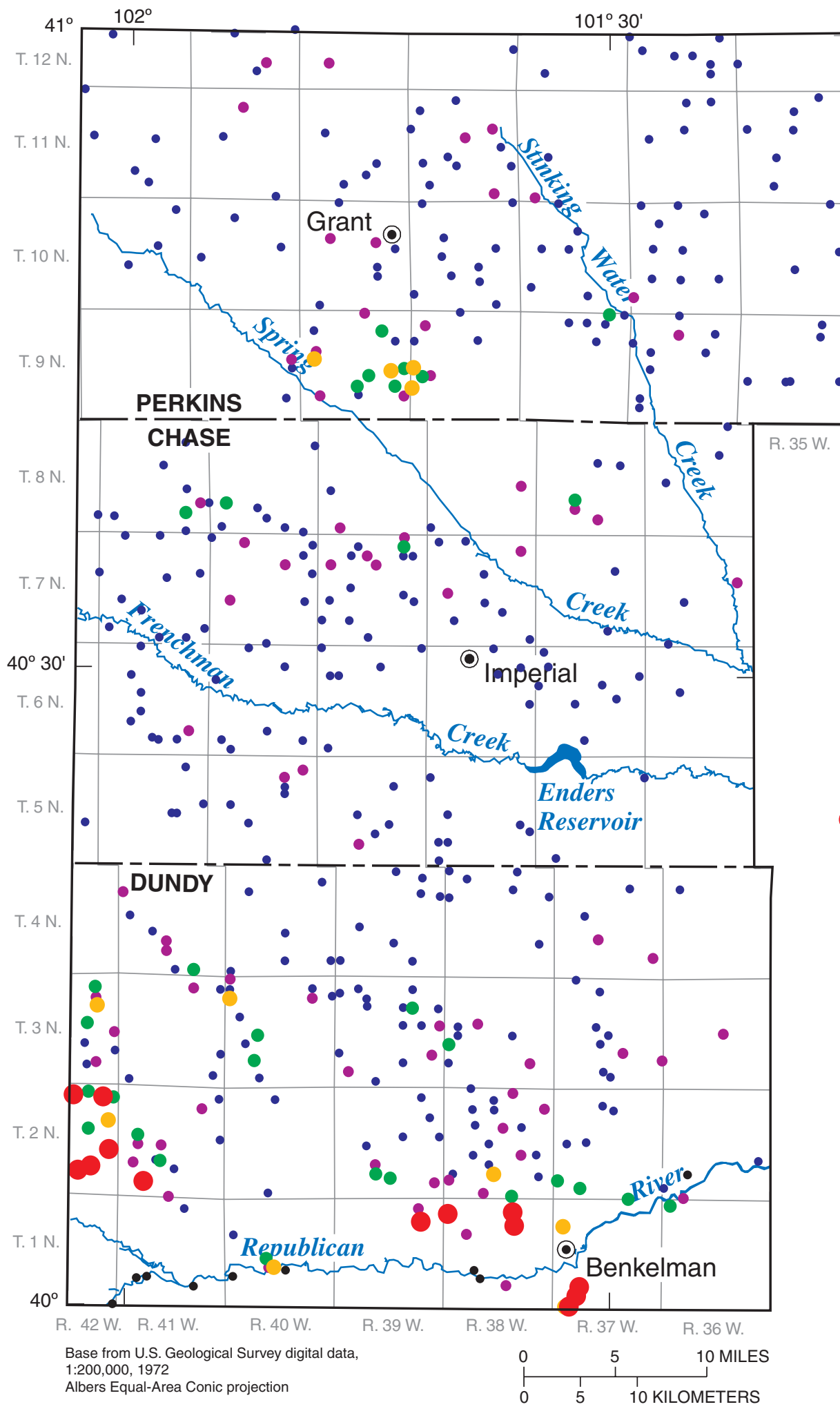

EXPLANATION

NITRATE CONCENTRATION,

IN MILLIGRAMS PER

LITER, IN IRRIGATION WELLS

- 0.03 to 1.0

- 1.01 to 3.9

- 4.0 to 5.9

- 6.0 to 7.9

8.0 to 9.9

10 to 20

Figure 6. Nitrate concentrations in ground water from selected irrigation wells, Upper Republican Natural Resources District, 1998-2000. 
Fourteen wells were added to the network in 1999 for a total of 382 registered wells. One-hundred fifty-one wells were selected randomly and sampled in 1999 to confirm the 1998 nitrate concentrations and to expand sample analyses by field screening for selected triazine herbicides (table 3). All samples with positive triazine field screening results were analyzed quantitatively for triazine herbicides. An additional 5 percent of the samples with negative screening results were sent to the analyzing laboratory for verification of the field screening results.

In 2000, 78 additional irrigation wells were selected to expand the irrigation-well network in areas with ground-water nitrate concentrations near, or exceeding, the URNRD's ground-water management-plan action level of $6 \mathrm{mg} / \mathrm{L}$, and in other areas of concern as identified by the URNRD (fig. 6 and table 3). Samples collected from all wells were analyzed for nitrates and field screened for triazine herbicides. All samples with positive triazine screening results, and an additional 5 percent of the samples with negative screening results, were analyzed quantitatively for triazine herbicides. A subset of the samples also was analyzed for major ions; tritium, to identify the approximate age of the ground water; and nitrogen isotopes, to identify potential sources of nitrogen detected in groundwater samples.

\section{Soil-Coring Site Selection and Sampling Strategy}

Soil samples were collected from the unsaturated zone at 29 spatially distributed sites (fig. 2; table 4 on CD-ROM) to evaluate changes in nitrogen concentrations at locations with varying soil characteristics and land-use practices. Additionally, data generated during this sampling effort provided information on the nitrogen content in the unsaturated zone that may influence future ground-water nitrate concentrations. At each coring site, a single core was collected at depths of as much as $50 \mathrm{ft}$ below the land surface or to the water table, whichever was shallower. From each core, approximately 10 soil samples were collected and analyzed for nitrate and ammonia concentrations.

\section{Water-Quality Sampling and Laboratory Analytical Methods}

All ground-water field measurements and samples were collected by USGS and URNRD personnel. Onsite, well integrity was evaluated; prevalent land use within a 1-mi radius of the site was documented; and potential point sources of contamination (such as septic tanks, feedlots, municipal dumps, and industry) were identified. Additional potential sources of contamination were chemical injection (chemigation) systems that producers often use to apply fertilizers or other chemicals to the fields with irrigation water. When a potential source of contamination was present at the site, or if a sample could not be collected from a faucet or spigot located between the water source and the chemigation point, the sampling process was discontinued, and arrangements were made to identify an alternate well.

At all domestic and irrigation wells, water samples were collected from a faucet or spigot located as close to the wellhead as possible. If a spigot was not present on a domestic well, a spigot was installed if the owner allowed it. If permission was not granted, an alternate well was selected. If a spigot was not present on an irrigation well, water for chemical analyses and the measurements of field parameters was collected from openings in the irrigation pipe or from the pivot/sprinkler, provided a chemigation system was not present at the site.

\section{Physical-Property and Major-Ion Measurements}

Measurements of specific conductance, $\mathrm{pH}$, and water temperature were made with the use of a flow-through chamber prior to sample collection. Flow to the chamber was limited to about 3 to $8 \mathrm{gal} / \mathrm{min}$, and measurements of these physical properties were collected every 3 minutes until the readings had stabilized. Physical properties were considered stable when the following criteria were met between two consecutive readings: (1) specific conductance remained within 5 percent; (2) $\mathrm{pH}$ remained within 0.1 standard unit; and (3) water temperature remained within $0.2^{\circ} \mathrm{C}$. Once the physical properties had stabilized, the flow-through chamber was disconnected and the ground-water sample was collected from the spigot. At irrigation wells where samples were collected from the irrigation pipe or pivot/sprinkler rather than a spigot, a single measurement of specific conductance, $\mathrm{pH}$, water temperature, and dissolvedoxygen concentration was made prior to sample collection. At most of these sites, the irrigation wells were pumping when personnel arrived, and it has been reported that the chemistry of water samples does not significantly change after 15 minutes of pumping (Zlotnik and others, 1995), so it was assumed that physical properties were stable and that samples would be representative of water in the aquifer.

Water samples from about one-third of the irrigation wells and all of the 2001 domestic-well sites were analyzed for dissolved major ions, including calcium, magnesium, sulfate, and chloride. Samples collected for analysis of major ions were filtered and preserved in accordance with the method described by Pritt and Jones (1989). The major ion samples were shipped to USGS National Water Quality Laboratory (NWQL) in Lakewood, Colorado, within 3 days of sample collection, and were analyzed using standard procedures described in Fishman and Friedman (1989).

\section{Coliform Bacteria and Nitrate}

All ground-water samples collected as part of this study from 1998 to 2000 were analyzed for coliform bacteria (total and fecal) and total nitrate (nitrate plus nitrite) by Olsen's Agricultural Laboratory in McCook, Nebraska, using USEPA Methods 5.6 and 353.2, respectively. Because both methods require the analysis of unfiltered, unpreserved water, samples 
for these analytical methods were collected directly from the faucet or spigot at the well. The samples were bottled and chilled to $4^{\circ} \mathrm{C}$ and transported to Olsen's Laboratory within 48 hours of sample collection.

The sampling procedure for bacteria was modified slightly for the 1999 domestic-well sampling because many of the domestic wells sampled in 1998 had positive test results for coliform bacteria. The 1998 water samples for bacteria were collected from a faucet or spigot that had not been sterilized prior to sample collection. As a result, it was impossible to determine if bacteria detected in the sample were actually present in the ground water or were introduced as a result of water coming into contact with the faucet or spigot. All samples collected for bacteria analyses in 1999 were collected following flame sterilization of the faucet or spigot. At 25 percent of the wells sampled in 1999, an additional sample to be analyzed for bacteria was collected, prior to sterilizing the spigot/faucet (using the 1998 procedures), to allow for a direct comparison of data from both sampling methods.

In 2001, the nutrient analyses of ground-water samples from domestic wells was expanded from analyzing for nitrate only, to include nitrite, ammonia, orthophosphate, and phosphorus. The samples were filtered through a 0.45 -micrometer $(\mu \mathrm{m})$ membrane filter. The filtered sample water was used to rinse the sample containers, the samples were chilled to $4^{\circ} \mathrm{C}$, and were shipped to the NWQL within 3 days of sample collection. Nutrient samples shipped to the NWQL were analyzed using standard procedures described by Fishman and Friedman (1989).

\section{Herbicides and Other Common-Use Pesticides}

In 1999 and 2000, water samples collected from irrigation wells were screened onsite for organonitrogen (triazine) herbicides using an immunoassay technique (Strategic Diagnosis Inc., 1997a, 1997b). All samples with positive test results (at least 0.1 microgram per liter $(\mu \mathrm{g} / \mathrm{L})$ of total triazines) and 5 percent of the samples with negative results were shipped to the NWQL for quantitative analysis of triazine herbicides (31 samples in 1999 and 23 samples in 2000). In 2001, 26 domesticwell samples were sent to the NWQL for analysis of a more comprehensive suite of pesticides (insecticides and herbicides, including the triazine herbicides). NWQL used gas chromatography with mass spectrometry (GC/MS) detection to measure concentrations of triazine herbicides (1999 and 2000 irrigationwell water samples) (Sandstrom and others, 1992) and common pesticides (2001 domestic-well water samples) (Zaugg and others, 1995).

\section{Tritium}

Tritium is produced naturally in the atmosphere, with natural levels in rainwater of about 5 to 10 tritium units (TU), but the most significant source of tritium is thermonuclear weapons testing that took place in the atmosphere between 1952 and 1969 (Drever, 1997). In 2000, ground-water samples from 25 irrigation wells were analyzed for tritium. Tritium samples were collected directly from the faucet or spigot, in glass bottles that had been pre-rinsed with unfiltered native water prior to sample collection. The bottles were sealed tightly to prevent evaporation and were shipped to the Environmental Isotope Laboratory (EIL), in the Department of Earth Sciences at the University of Waterloo in Waterloo, Ontario, Canada. The samples were analyzed for tritium (enriched method) (Environmental Isotope Laboratory, 1998).

\section{Nitrogen Isotopes}

In 2000, ground-water samples from 25 irrigation wells were analyzed for nitrogen isotopes. Samples analyzed for nitrogen isotopes (nitrogen $15\left({ }^{15} \mathrm{~N}\right) /$ nitrogen $14\left({ }^{14} \mathrm{~N}\right)$ as nitrate) were collected as described in the NWQL's Technical Memo 95.05, and were shipped to the NWQL, as soon after collection as possible for analysis by mass spectrometry. For this report, conventional nomenclature was used in the analyses of water samples for nitrogen isotopes. The composition of stable isotopes of low-mass (light) elements such as nitrogen generally is reported using the delta $(\delta)$ notation, which indicates parts per thousand or per mil. The general expression for the $\delta$ value is calculated by equation 1 :

$$
\delta\left(\text { per mil) }=\left[\frac{R_{X}}{R_{S}}-1\right] \times 1,000\right.
$$

where $R_{x}$ is the ratio of the heavy-to-light isotope of the sample and $R_{S}$ is the ratio of the heavy-to-light isotope of the standard (for example ${ }^{15} \mathrm{~N} /{ }^{14} \mathrm{~N}$ ) (Kendall and Caldwell, 1998).

\section{Soil-Core Sampling and Laboratory Analyses}

The soil cores were collected at 29 sites (fig. 2 and table 4) with a hydraulic probe operated by University of NebraskaLincoln (UN-L) Water Center personnel, as described in their standard operating procedures. Continuous cores were collected at each of the sites to a depth of $50 \mathrm{ft}$, if possible. Coring was limited to depths of less than $50 \mathrm{ft}$ below land surface in cases where the hydraulic probe encountered an impenetrable soil layer (e.g. substantial layer of caliche) or the water table. As many as 10 samples were collected from each core at sampling intervals of 4 to $5 \mathrm{ft}$, or where warranted based on changes in soil lithology. Soil samples were placed in paper boxes and were transported to the Department of Agronomy Soil-Testing Laboratory at UN-L as soon as possible after soil-core collection. The Soil Testing Laboratory analyzed soil samples for nitrate and ammonia using EPA methods 353.2 (U.S. Environmental Protection Agency, 1993) and 350.1 (U.S. Environmental Protection Agency, 1983). Total nitrogen content for each soil-sample interval (table 4) was derived by adding reported concentrations for nitrate and ammonium, and converting them from milligrams/kilogram $(\mathrm{mg} / \mathrm{kg})$ as nitrogen to pounds per acre (lb/acre), a unit commonly used by the agricultural 
community. The mean total nitrogen (lb/acre) also was calculated for each soil core. The units were converted by applying equation 2 (modified from Follett and others, 1991):

$$
\begin{gathered}
\text { Total nitrogen content }(\mathrm{lb} / \mathrm{acre} \text { as } \mathrm{N}) \\
=\text { Total nitrogen }(\mathrm{mg} / \mathrm{kg} \text { as } \mathrm{N}) \\
\mathrm{x} 0.3 \mathrm{x} \text { length of core (in.) }
\end{gathered}
$$

where total nitrogen $(\mathrm{mg} / \mathrm{kg}$ as $\mathrm{N})$ is the sum of ammonium and nitrate (both in $\mathrm{mg} / \mathrm{kg}$ as $\mathrm{N}$ ); 0.3 is the unit conversion factor; and the length of core refers to the interval sampled, in inches.

\section{Data Analysis}

Statistical methods were used to describe and characterize the general water chemistry of the study area. Variations between data sets were determined by nonparametric statistical analysis, which relies on the conversion of data to ranked values and does not require that the data be normally distributed (Dowdy and Wearden, 1991). Data were grouped into appropriate subgroups, and all values reported as less than the method reporting limit (censored data) were assigned a value equal to one-half the method reporting limit. A value of one-half the method reporting limit assures that the censored data are smaller than the smallest reported concentration, but does not rely on the assumption that concentrations lower than the method reporting limit for a given analytical method indicate that a compound is not present in the sample. As the statistical methods used in data analysis are nonparametric and compare populations by ranking the data, assigning a minimum value to the censored data does not affect the test results (Helsel and Hirsch, 1992).

The data were analyzed using the Wilcoxon rank-sum test for large samples sets (more than 15 samples) (Dowdy and Wearden, 1991; Helsel and Hirsch, 1992). The Wilcoxon ranksum test was used to determine if paired chemical concentrations were significantly different, such as data collected from the same well but on separate days. All statistical analyses used a confidence level of 95 percent $(\alpha=0.05)$ and were evaluated using a p-value. For this study, if the p-value was less than or equal to 0.05 , a statistically significant difference existed between the two populations. If the p-value was greater than 0.05 , no statistically significant difference existed between the two populations.

Correlation analysis was used on some sample sets to determine if values for two variables were associated (Dowdy and Wearden, 1991; Helsel and Hirsch, 1992). The correlation coefficient ( $r$ ) was used to determine the strength of the association. Generally the closer the $\mathrm{r}$ value is to 1.0 or -1.0 , the stronger the association.

\section{Quality Assurance and Quality Control}

Quality assurance (QA)/quality control (QC) sampling consisted of the collection of duplicate, blank, and reference samples. About 10 percent of all water-quality (analyzed for nitrate and in some cases other nitrogen and phosphorus compounds, coliform bacteria, triazine herbicides, common pesticides, major ions, tritium, and nitrogen isotopes) and soil samples (analyzed for nitrate and ammonium) were collected for duplicate analyses. Additionally, equipment blanks (about 3 percent) and reference samples (about 1 percent) were sent to Olson's Laboratory for nitrate analyses. For further verification of the nitrate results from Olsen's Laboratory, a portion of the QC samples consisted of duplicate samples sent to the NWQL for nitrate analyses. As mentioned previously, all pesticide samples with a total triazine concentration of at least $0.1 \mu \mathrm{g} / \mathrm{L}$ (based on immunoassay screening results) and 5 percent of the samples with negative results were shipped to the NWQL for quantitative analysis of triazine herbicides using GC/MS. In addition to internal $\mathrm{QA} / \mathrm{QC}$ procedures at each laboratory, USGS personnel reviewed all data to assure consistency and reliability.

\section{Characterization of Ground-Water Quality}

Although water-quality sampling procedures were similar for the domestic and irrigation wells, the analytical results from the two sampling efforts are presented separately in this section. Because the majority of the domestic wells included in the network are not registered with the State of Nebraska, driller's log or other well-construction information could not be located, which made the identification of source waters in the groundwater system impossible. Because of the availability of wellconstruction information and driller's logs for wells in the irrigation-well network, part of the data analysis focuses on location of the constituents within the ground-water system. Summary statistics for selected water-quality constituents are presented in table 5 (on CD-ROM) for samples from the domestic wells and in table 6 (on CD-ROM) for samples from the irrigation wells.

\section{Domestic-Well Network}

As mentioned previously, 101 wells in the domestic-well network were sampled in 1998, with additional sampling in 1999 and 2001 generally limited to a subset of the initial 101 wells. Despite the lack of well-construction data for most wells in the domestic-well network, it is critical to assess water quality of the drinking-water supplies for rural residents in the URNRD.

\section{Physical-Property and Major-Ion Measurements}

Physical properties were collected at each well prior to sample collection. The physical properties that were measured routinely at the domestic wells included specific conductance, 
$\mathrm{pH}$, and water temperature (table 5). Specific conductance is the measure of the electrical conductivity of water and is deter-

mined by the species and concentrations of dissolved solids in the water. The specific conductance measured in samples collected from domestic wells during 1998 to 2001 varied widely from 208 to 3,421 microsiemens per centimeter at $25^{\circ} \mathrm{C}$ $(\mu \mathrm{S} / \mathrm{cm})$, with a median value of $374 \mu \mathrm{S} / \mathrm{cm}$. The $\mathrm{pH}$ of a sample is a measurement of the hydrogen-ion activity and is expressed as the negative base-10 logarithm of hydrogen activity in moles per liter (Hem, 1985). Measurements of $\mathrm{pH}$ in domestic wells sampled from 1998 to 2001 ranged from 6.1 to 8.7 standard units, with a median value of 7.6 standard units. The water temperature in the domestic-well samples varied from 12.6 to $20.1^{\circ} \mathrm{C}$, with a median value of $15.0^{\circ} \mathrm{C}$.

Natural water commonly contains 8 to 10 major ions including cations (positively charged ions) and anions (negatively charged ions), with 7 of the major ions (calcium, magnesium, sodium, potassium, chloride, sulfate, and bicarbonate) making up the bulk of the dissolved-solids load in almost all natural ground-water samples around the world (Briel, 1993). In a trilinear diagram (fig. 7), results from each domestic-well sample analyzed for major ions in 2001 were plotted in the lower left triangle by percentage (in milliequivalents per milliliter) of total cations, and in the lower right triangle by percentage of total anions. Straight lines drawn from these two points are used to generate a third point in the diamond field indicating the overall chemical composition of the water. Data points representing water from the domestic wells generally fell within the leftmost subarea of the diamond field, which indicates that the water is a calcium magnesium bicarbonate type, typical of the Ogallala Group of the High Plains aquifer (Engberg and Druliner, 1988). Water from two of the domestic wells differed slightly in chemical composition from water from the other domestic wells, with major-ion concentrations indicative of a calcium magnesium sulfate water type.

\section{Coliform Bacteria}

Of the 101 samples collected from domestic wells in 1998, 26 percent tested positive for the presence of coliform bacteria (table 2), exceeding the MCL of zero colonies (U.S. Environmental Protection Agency, 2002). The number of colonies ranged from 0 to greater than 200 per 100 milliliters $(\mathrm{mL})$ of water (tables 2 and 5). Although 9 of the 26 samples that tested positive for total coliform bacteria had nitrate concentrations greater than $3 \mathrm{mg} / \mathrm{L}-\mathrm{a}$ threshold considered indicative of influence from human sources (Madison and Brunett, 1985), there is no apparent association between the presence of bacteria and elevated nitrate concentrations $(r=-0.09)$ in samples from the domestic wells.

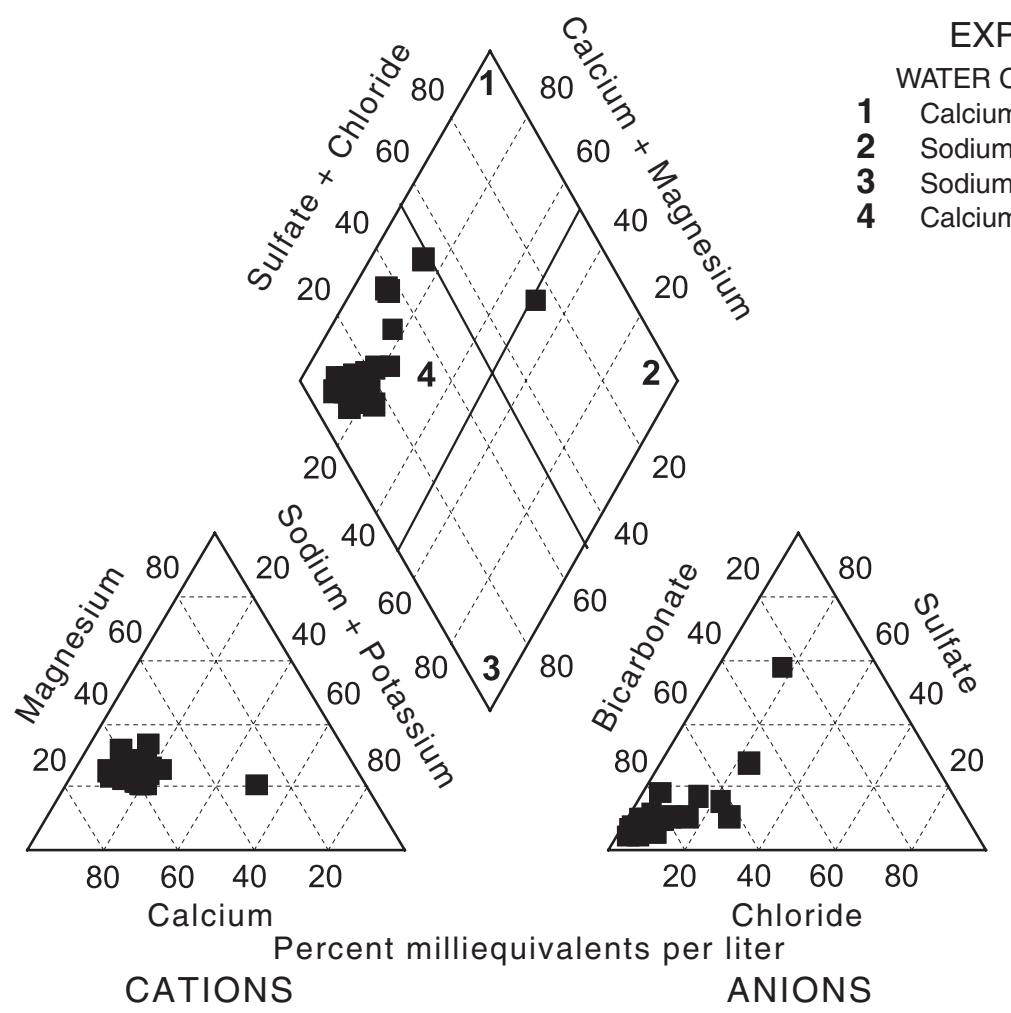

Figure 7. Water types for samples from selected domestic wells, Upper Republican Natural Resources District, 2001. 
In 1999, samples were collected from wells for which the 1998 analytical results either indicated a positive test for coliform bacteria or ground-water nitrate concentrations were greater than $6 \mathrm{mg} / \mathrm{L}$. Of the domestic wells that were resampled, samples from 14 wells again tested positive for total coliform bacteria. Also, samples from two wells that had tested negative for coliform bacteria in 1998 samples, tested positive in 1999. Two samples collected in 1999 had positive tests for total coliform (1 colony per $100 \mathrm{~mL}$ ) using the 1998 sampling methodology, and the environmental samples had negative results following flame sterilization (table 7 on CD-ROM). All additional samples had comparable results regardless of the use of flame sterilization, with no significant differences between the 1998 and 1999 bacteria data (Wilcoxon rank-sum test p-value $=0.41$ ). Small differences between 1998 and 1999 results were likely the result of natural variability in the presence of bacteria in the water.

\section{Nitrates}

Nitrates were detected in water from every domestic well sampled from 1998 to 2001 (fig. 5 and table 5). In 1998, nitrate concentrations ranged from 0.03 to $24 \mathrm{mg} / \mathrm{L}$ (median $2.2 \mathrm{mg} / \mathrm{L}$ ) (table 2). Similar ranges in concentrations of nitrate were detected in domestic-well samples collected during 1999 and 2001, but the focus of these sampling efforts in areas with elevated nitrate concentration resulted in higher median nitrate concentrations of $3.5 \mathrm{mg} / \mathrm{L}$ in 1999 and $4.6 \mathrm{mg} / \mathrm{L}$ in 2001 .

Nitrate concentrations in 8 percent of the ground-water samples collected equalled or exceeded the MCL of $10 \mathrm{mg} / \mathrm{L}$ (samples from four wells sampled in 1998, four wells in 1999, and four wells sampled in 2001) (table 2). Comparisons of nitrate data from wells that were resampled did not show significant differences in the concentrations using Wilcoxon rank-sum tests $(1998 \mathrm{p}$-value $=0.37 ; 1999 \mathrm{p}$-value $=0.45 ;$ and $2001 \mathrm{p}$-value $=$ 0.41 ). Because of the lack of differences in nitrate concentrations between sampling years, figure 5 shows only the initial nitrate concentrations measured at each of the domestic wells.

\section{Herbicides and Other Common-Use Pesticides}

All ground-water samples collected from domestic wells in 2001 were analyzed for pesticide compounds. Twelve of the 26 samples (46 percent) contained detectable concentrations of pesticides. Although a large number of pesticides were included in the analyses (table 2), only the organonitrogen (triazine) herbicides of atrazine, metolachlor, and prometon, and the atrazine degradation product, deethylatrazine, were detected. Atrazine was detected in nine ( 35 percent) of the samples. The maximum concentration of atrazine detected in the samples was $0.17 \mu \mathrm{g} / \mathrm{L}$, which is less than the USEPA's MCL of $3.0 \mu \mathrm{g} / \mathrm{L}$. Metolachlor also was detected in three of the samples that contained atrazine, but generally was detected at higher concentrations (table 2). Prometon was detected in one sample at a concentration of $0.11 \mu \mathrm{g} / \mathrm{L}$. The atrazine degradation product, deethylatrazine, was found in 11 (42 percent) of the samples and was the most frequently detected pesticide. Because of little or unavailable well-construction information, the aquifer or hydrogeologic unit that is the source of water containing the pesticides cannot be determined.

\section{Irrigation-Well Network}

The irrigation-well network consisted of 368 wells that were sampled in 1998 (table 3). Additional wells were added in 1999 and 2000 to improve spatial coverage of the well network.

\section{Physical-Property and Major-Ion Measurements}

During the study, specific conductance measured in irrigation-well samples varied widely from 158 to $3,330 \mu \mathrm{S} / \mathrm{cm}$ (median $363 \mu \mathrm{S} / \mathrm{cm}$ ) (table 6). All but two wells with specific conductance values greater than $1,000 \mu \mathrm{S} / \mathrm{cm}$ were located near the Republican River in Dundy County. In samples from the irrigation wells, $\mathrm{pH}$ ranged from 6.3 to 8.5 (median 7.6), and water temperature ranged from 11.6 to $25.0^{\circ} \mathrm{C}$ (median $15.2^{\circ} \mathrm{C}$ ). Dissolved oxygen also was measured routinely in samples from the irrigation wells, with concentrations ranging from 0.5 to $12.0 \mathrm{mg} / \mathrm{L}$ (median $8.1 \mathrm{mg} / \mathrm{L}$ ). Although a trilinear diagram of the major-ion analyses of water from the irrigation wells (fig. 8 and table 3 ) generally showed a calcium magnesium bicarbonate composition typical of water from the Ogallala Group of the High Plains aquifer (Engberg and Druliner, 1988), water from some irrigation wells had elevated sulfate concentrations, and plotted as a calcium magnesium sulfate type water. The elevated sulfate concentrations may originate from the oxidation of thin bands of iron pyrite in many horizons of the underlying Pierre Shale.

\section{Nitrates}

From 1998 to 2000, ground-water samples were collected from 460 irrigation wells in the URNRD study area and were analyzed for nitrate. Figure 6 shows only the initial nitrate concentrations measured at each of the irrigation wells. Nitrate concentrations in water from the wells during the 3-year sampling period ranged from less than 0.03 (for four samples) to $26 \mathrm{mg} / \mathrm{L}$, with a median concentration of $2.7 \mathrm{mg} / \mathrm{L}$ (fig. 6 and table 6). Of all samples collected from irrigation wells, about 3 percent exceeded the MCL for nitrate.

Nitrate concentrations in samples from 368 wells in 1998 ranged from less than the method reporting limit of $0.03 \mathrm{mg} / \mathrm{L}$ to $25 \mathrm{mg} / \mathrm{L}$ (median $2.5 \mathrm{mg} / \mathrm{L}$ ) (table 3). In 1999, 138 of these wells were sampled again to verify the concentrations of nitrate detected, and to expand the constituents included in the analyses. Comparison of the 1998 and 1999 nitrate data collected from the 138 wells showed no significant difference $(\mathrm{p}$-value $=$ 0.89 ) between data collected in those years. In addition to resampling wells, 14 wells were added to the irrigation-well sampling network in 1999. The irrigation-well network was 


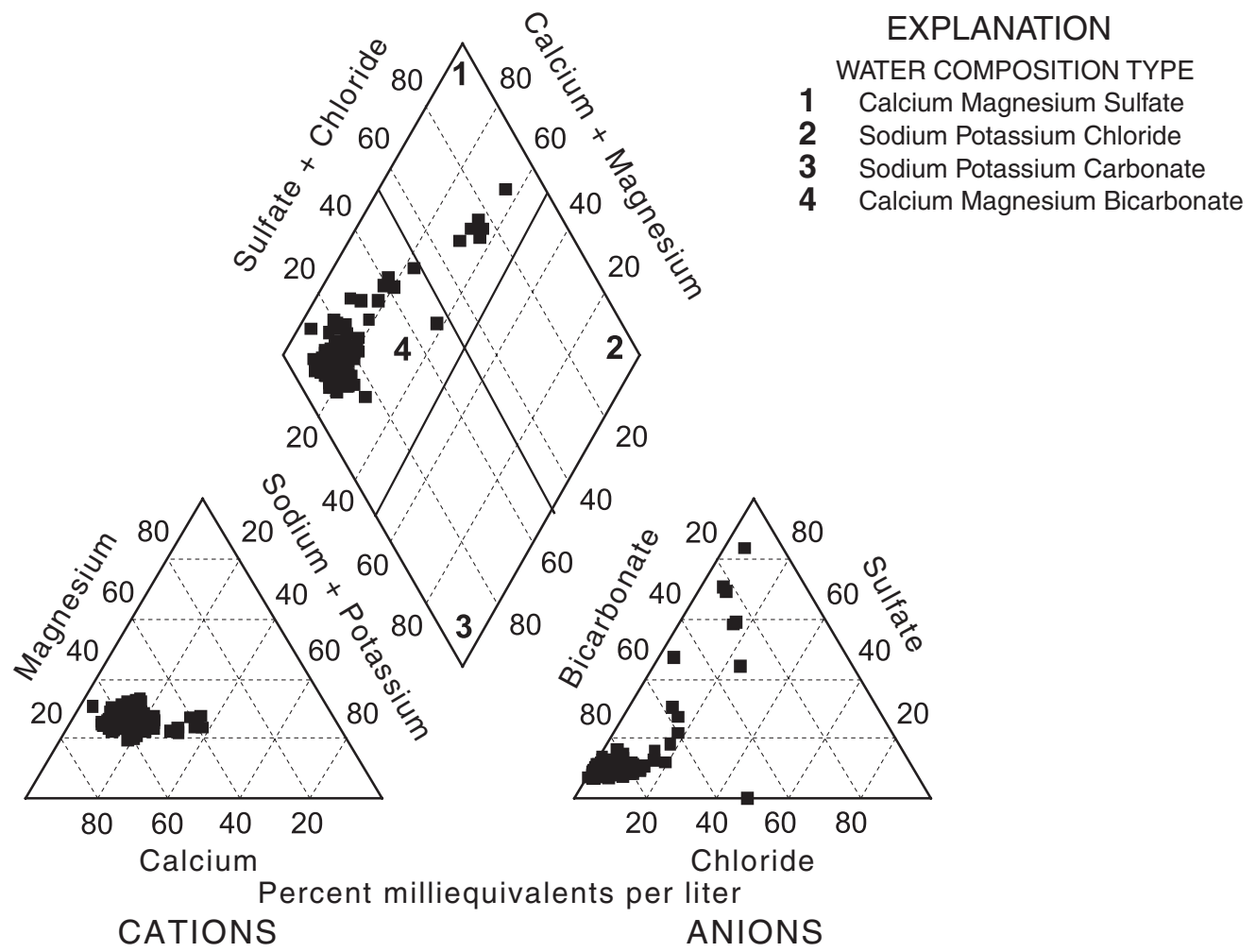

Figure 8. Water types for samples from selected irrigation wells, Upper Republican Natural Resources District, 1998-2000.

expanded again in 2000 to include 78 additional wells in areas with elevated nitrate concentrations, as well as other areas of concern, as identified by the URNRD. Possibly because of the emphasis on locating wells in areas with elevated nitrate concentrations, the median concentration of nitrates detected in 2000 increased to $4.5 \mathrm{mg} / \mathrm{L}$ from $2.5 \mathrm{mg} / \mathrm{L}$ in 1998 and $2.6 \mathrm{mg} / \mathrm{L}$ in 1999 (table 3).

Areas with nitrate concentrations greater than or equal to $6.0 \mathrm{mg} / \mathrm{L}$ in ground water were predominantly in north-central Chase, western and south-central Dundy, and south-central Perkins Counties (fig. 6). Soils in these areas generally consist of sand to sandy loam (fig. 2) with permeabilities ranging from 6 to $20 \mathrm{in} / \mathrm{hr}$, and a high percentage of cropland. Although nitrate concentrations in samples from wells located near the Republican River varied widely, ranging from less than the method reporting limit of $0.03 \mathrm{mg} / \mathrm{L}$ to more than $25 \mathrm{mg} / \mathrm{L}$, the median concentration $(1.9 \mathrm{mg} / \mathrm{L})$ was below the background nitrate concentrations expected for uncontaminated ground water in the United States (Madison and Brunett, 1985; McMahon, 2001). The number of wells with low nitrate concentrations may be the result of denitrification occurring in areas with sufficient organic matter and anaerobic conditions in an area with a shallow water table (Starr and Gillham, 1993).

\section{Herbicides and Other Common-Use Pesticides}

Atrazine, one of the triazine herbicides, is used extensively in the URNRD to reduce loss of crop productivity because of weed proliferation. Atrazine is used alone or in combination with other herbicides such as alachlor and metolachlor. Because atrazine is relatively water soluble with a low affinity for solid surfaces (Nowell and others, 1999) and is used extensively in the URNRD area, it has potential to contaminate ground water. A survey of samples from more than 2,000 wells in Nebraska found that 13.5 percent of them were contaminated with atrazine, although only 1 percent had concentrations greater than $3 \mu \mathrm{g} / \mathrm{L}$ (Comfort and Roeth, 1996).

Of the irrigation-well samples screened for pesticides during 1999 and 2000 (table 3), 54 were sent to the NWQL for GC/MS analysis. Atrazine and deethylatrazine, a degradation product of atrazine, were detected in a substantial number of the 1999 samples. Of the 31 samples analyzed in 1999, 14 (45 percent) had detectable concentrations of atrazine (with a maximum concentration of $0.22 \mu \mathrm{g} / \mathrm{L}$ ), and 13 (42 percent) had detections of deethylatrazine (with a maximum concentration of $0.96 \mu \mathrm{g} / \mathrm{L}$ ). Metolachlor, propazine, and trifluralin were the only other pesticides detected in 1999. Because all concentrations of these compounds detected were near the method 
reporting limit, the results were reported as estimated values or as detected but not at a concentration that could be quantified (table 3).

Although fewer samples were sent to NWQL for pesticide analysis in 2000 than previous years, the number of pesticides detected increased, as did the number of detections of atrazine, deethylatrazine, and metolachlor. Of the 23 samples analyzed during 2000, all had detectable concentrations of atrazine, and 19 samples (83 percent) had detectable concentrations of deethylatrazine. Metolachlor was detected in 16 samples, with concentrations ranging from an estimated concentration of 0.01 to $0.38 \mu \mathrm{g} / \mathrm{L}$ (table 3 ). Acetochlor, alachlor, metolachlor, prometon, propachlor, and propazine also were detected in irrigation-well samples collected during 2000. Out of the 23 samples collected during 2000, acetochlor was detected in 7 samples, alachlor in 7 samples, prometon in 3 samples, propachlor in 9 samples, and propazine in 6 samples (table 6). All concentrations of atrazine and alachlor were less than the MCLs of 3.0 and $2.0 \mu \mathrm{g} / \mathrm{L}$, respectively (U.S. Environmental Protection Agency, 2002). The increase in the number of pesticide detections in the 2000 samples may be the result of selecting wells in areas vulnerable to nonpoint-source contamination as indicated by elevated concentrations of nitrates in the ground water.

Atrazine and deethylatrazine were detected together in 13 samples collected during 1999, and in 18 samples collected during 2000. The deethylatrazine-to-atrazine ratio (DAR) has been used by Adams and Thurman (1991) as an indicator of nonpoint-source pollution of ground water. Deethylatrazine is more mobile than atrazine and typically leaches through soil and into ground water. Large DAR values, greater than 0.7, indicate the possibility that atrazine has been transported slowly into the ground-water system and considerable deethylation of atrazine by soil microorganisms has occurred. A small DAR ratio (about 0.1 ) was found when minimum degradation of atrazine had occurred, evidence of the rapid transport of atrazine into the aquifer. DAR values were calculated for 30 of the irrigation-well water samples collected in 1999 and 2000, including 15 values based on estimated concentrations (table 3 ). DAR values greater than 0.7 were calculated for 26 ( 87 percent) of the samples. The lowest calculated DAR value was 0.27 , and the median DAR value for the 31 wells was 3.7. Generally, the large DAR values calculated for wells in the URNRD indicate that atrazine has been transported slowly into ground water-a conclusion consistent with a nonpoint source of contamination. The four samples with DAR values less than 0.7 were from wells with depths greater than $200 \mathrm{ft}$. Of the four samples, three also had detectable concentrations of acetochlor, alachlor, and metolachlor, and one of the three had detectable concentrations of prometon and propachlor as well. Based on the locations of these wells, most appear to be in areas with sandy to sandyloamy soil. With permeability in these soils ranging from 7 to $20 \mathrm{in} / \mathrm{hr}$ (Soil Conservation Service, 1963; 1982; and 1991), agricultural chemicals applied to fields in these areas could move rapidly through the soil.

\section{Tritium}

Tritium in ground water is not significantly affected by chemical processes. Although it cannot be used to age-date water due to uncertainties caused by mixing of water, it can be used to distinguish between water that entered the aquifer system prior to 1952 (Drever, 1997) and water that has been recharged after 1952. Water entering the system prior to 1952 will not have detectable concentrations of tritium; water entering the system since 1952 will have concentrations substantially greater than 10 to $20 \mathrm{TU}$ (Fetter, 1988). Water from mixed sources will have concentrations between the method detection limit and 20 TU (Drever, 1997; Fetter, 1988).

Samples collected from 25 of the wells sampled in 2000 were analyzed for tritium concentrations. Samples from eight of the wells (about one-third of the sites sampled) had tritium concentrations less than the method detection limit of $0.8 \mathrm{TU}$, indicating that water in these wells entered the system prior to 1952 (fig. 9). Because agricultural practices in the area increased in the 1950s and 1960s, it can be assumed that this water was not influenced by agricultural chemicals. This assumption is supported by nitrate concentrations measured in water samples taken from these wells. The median nitrate concentration from samples with no detectable amount of tritium was $3.0 \mathrm{mg} / \mathrm{L}$. This nitrate concentration is similar to the nitrate concentrations considered to be naturally occurring (Madison and Brunett, 1985; McMahon, 2001). Samples with detectable concentrations of tritium had elevated concentrations of nitrate, ranging from 3.6 to $12 \mathrm{mg} / \mathrm{L}$ (median $=7.0 \mathrm{mg} / \mathrm{L}$ ) (table 3).

\section{Nitrogen Isotopes}

Because most sources of nitrate typically have distinct isotopic signatures, nitrogen isotopes have been used to distinguish between anthropogenic and natural sources of nitrate. Sources of nitrogen from animal waste generally have $\delta^{15} \mathrm{~N}$ values greater than 10 per mil, whereas sources of nitrogen from synthetic fertilizers generally have $\delta^{15} \mathrm{~N}$ values less than 2 per mil (Kendall, 1998). Values between 2 and 10 per mil are typically considered background values, or indicative of water that is a mix of the two sources.

In 2000, nitrogen-isotope analyses were performed on water samples from 25 irrigation wells located in areas of concern as identified from the high nitrate concentrations in samples collected in 1999. The $\delta^{15} \mathrm{~N}$ values measured in these water samples ranged from 0.4 to 9.8 per mil. Two of three sites with $\delta^{15} \mathrm{~N}$ values less than 2.0 per mil had samples with elevated nitrate concentrations and detectable amounts of tritium, indicating a possible nitrate source of synthetic fertilizer (fig. 9). Although $\delta^{15} \mathrm{~N}$ values in samples from three wells approached 10 per mil, the minimum value for an animal-waste source, none exceeded it. It is likely that the nitrogen source in these water samples is a mix of fertilizers and animal waste, possibly with a greater influence from animal waste. It should 


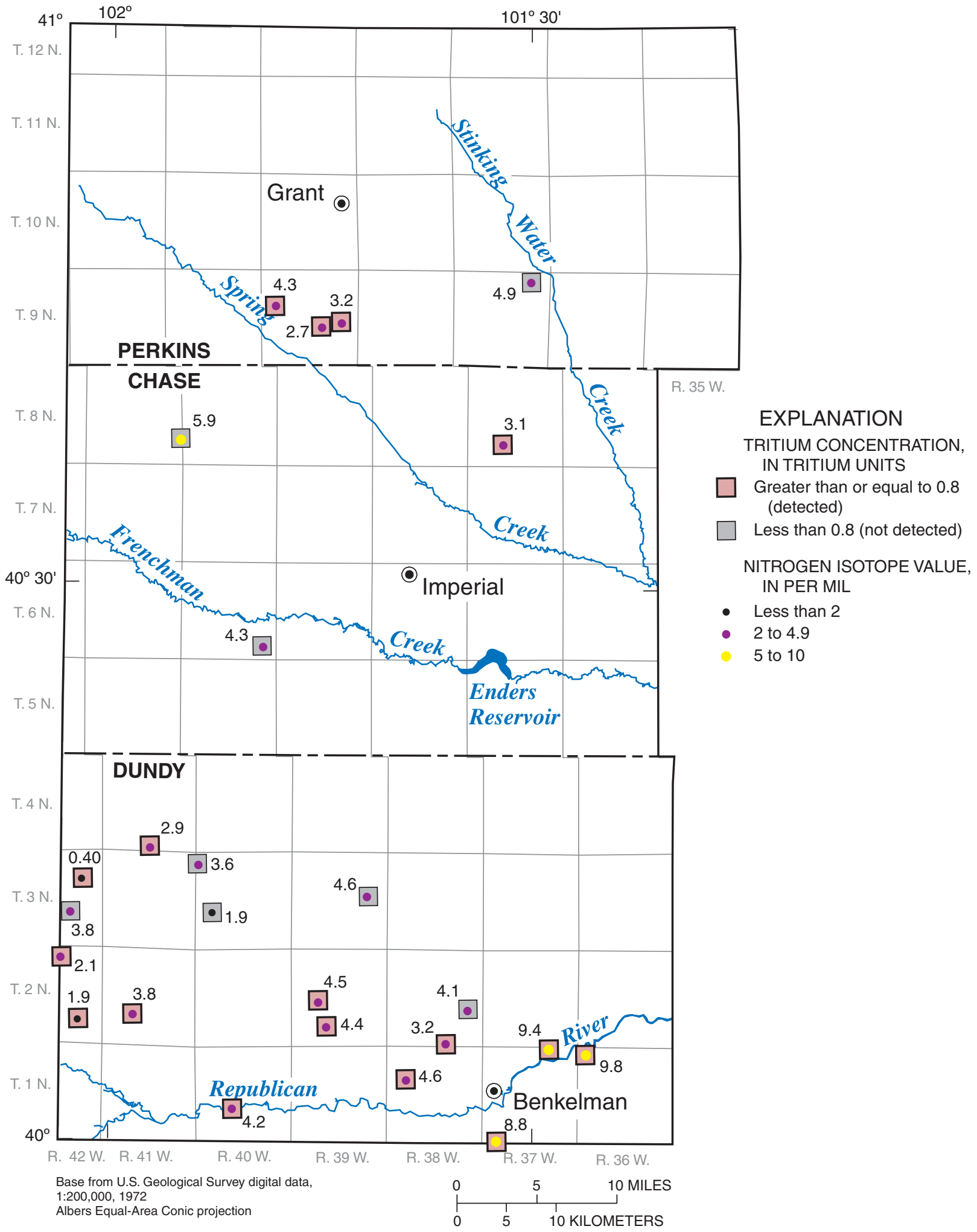

Figure 9. Tritium and nitrogen-isotope values in water samples from selected irrigation wells, Upper Republican Natural Resources District, 2000. 
be noted that reducing or anaerobic environments with dissolved-oxygen concentrations less than $1.0 \mathrm{mg} / \mathrm{L}$, can cause denitrification of nitrogen from synthetic fertilizer, which yields residual nitrates that have much higher $\delta^{15} \mathrm{~N}$ values and are isotopically indistinguishable from animal waste (Kendall, 1998). Although the water samples analyzed for this report contained dissolved-oxygen concentrations greater than $1.0 \mathrm{mg} / \mathrm{L}$, it is possible that one well sample with an elevated nitrogen-isotope value was influenced by reducing conditions. The well was shallow, located adjacent to the Republican River, and samples had a relatively low dissolved-oxygen concentration $(2.7 \mathrm{mg} / \mathrm{L})$ compared to samples from other irrigation wells. Based on the shallow depth to water and the likely presence of organic material, it is possible that some of the water pumped by this high-capacity well had undergone denitrification.

The $\delta^{15} \mathrm{~N}$ values in samples from the remaining wells generally were less than 5 per mil. At 12 of these wells, samples had nitrate values greater than $3.0 \mathrm{mg} / \mathrm{L}$ and detectable concentrations of tritium, indicating an anthropogenic source of nitrate (fig. 9). The $\delta^{15} \mathrm{~N}$ values in samples from these sites ranged from 2.1 to 4.6 per mil, indicating that nitrate present in the samples may be from mixed sources of animal waste and synthetic fertilizers, with a greater influence from synthetic fertilizers.

\section{Soil Nitrogen}

Soil-core sampling sites were selected to represent a variety of local land uses. Although nitrogen content in soil varied among and within all 29 sites (table 4), some general patterns were found based on land use. In general, land used as grassland or nonirrigated cropland had lower total nitrogen content, in the range of 15 to $25 \mathrm{lb} / \mathrm{acre}$, throughout the core with an increase in nitrogen content to about $40 \mathrm{lb} / \mathrm{acre}$ in the deeper soil samples (fig. 10). Although the same general pattern was noted in soil samples collected from areas with irrigated cropland, the nitrogen content measured was more variable with higher nitrogen content generally found throughout the sample (fig. 10). Statistical comparisons of the mean total nitrogen content also indicate that the apparent differences in soil nitrogen content are related to land use ( $\mathrm{p}$-value $=0.03$ ). Mean total nitrogen content of samples from rangeland and nonirrigated cropland were not significantly different (Wilcoxon rank-sum test $\mathrm{p}$-value $=0.60$ ), but the nitrogen content in soil samples from irrigated cropland was slightly higher than that measured in samples collected from rangeland ( $\mathrm{p}$-value $=0.10$ ) and significantly higher than nonirrigated cropland areas ( $\mathrm{p}$-value $=$ 0.01 ). The increase in total nitrogen concentrations with depth, and the elevated mean total nitrogen content in samples collected from areas of irrigated cropland, may be an indication that nitrogen was carried beyond the root zone of plants by infiltration of irrigation water.

\section{Summary and Conclusions}

The development of ground-water irrigation and the associated use of agricultural chemicals have increased the potential for leaching of fertilizers and other chemicals into ground water of the Upper Republican Natural Resources District (URNRD). In 1998, the U.S. Geological Survey, in cooperation with the URNRD, began a study to characterize the quality of ground water in the URNRD area with respect to physical properties and concentrations of major ions, coliform bacteria, nitrate, and pesticides, and to assess the presence of nitrogen concentrations in the unsaturated zone. At selected well sites, the ground-water quality characterization also included tritium and nitrogenisotope analyses to provide information about the approximate age of the ground water and potential sources of nitrogen detected in ground-water samples, respectively.

The water type in the majority of the domestic and irrigation wells sampled was a calcium magnesium bicarbonate composition, which is typical of water from the Ogallala Group of the High Plains aquifer. Samples from some wells near the Republican River were of a calcium magnesium sulfate composition, with elevated sulfate concentrations probably resulting from leaching of the underlying Pierre Shale.

Of the 101 domestic-well water samples collected in 1998, 26 tested positive for total coliform bacteria, exceeding the U.S. Environmental Protection Agency's Maximum Contaminant Level of zero colonies. Although several samples tested positive for total coliform bacteria and had elevated concentrations of nitrate (greater than 3 milligrams per liter $(\mathrm{mg} / \mathrm{L})$ ), no apparent association exists between the presence of bacteria and elevated nitrate concentrations. In 1999, water from a domestic well was resampled if the 1998 analysis for coliform bacteria was positive, or if the ground-water nitrate concentration was greater than $6 \mathrm{mg} / \mathrm{L}$. The 1999 sampling protocol was modified to include a flame sterilization process prior to sample collection, and at a subset of the sites, samples were collected using both the 1998 and 1999 sampling procedures. Data comparisons showed no significant differences between 1998 and 1999 bacteria detections (Wilcoxon rank-sum test $\mathrm{p}$-value $=0.41$ ).

Nitrates were detected in all ground-water samples collected from domestic wells and in all but four irrigation-well samples. Nitrate concentrations varied widely, ranging from less than the method reporting limit of 0.03 to $26 \mathrm{mg} / \mathrm{L}$. Nitrate concentrations less than the method reporting limit were measured in irrigation wells located near the Republican River. The low nitrate concentrations may be the result of denitrification occurring when sufficient organic matter and anaerobic conditions are present in an area with a shallow water table. The median nitrate concentrations in irrigation wells sampled in $1998(2.5 \mathrm{mg} / \mathrm{L})$ and $1999(2.6 \mathrm{mg} / \mathrm{L})$ indicate that the majority of wells sampled had nitrate concentrations that may be considered naturally occurring. In 1998, the median nitrate concentration in domestic-well samples was $2.2 \mathrm{mg} / \mathrm{L}$. The focus of domestic-well sampling efforts in areas with elevated nitrate concentrations in 1999 and 2001 is apparent because the median 

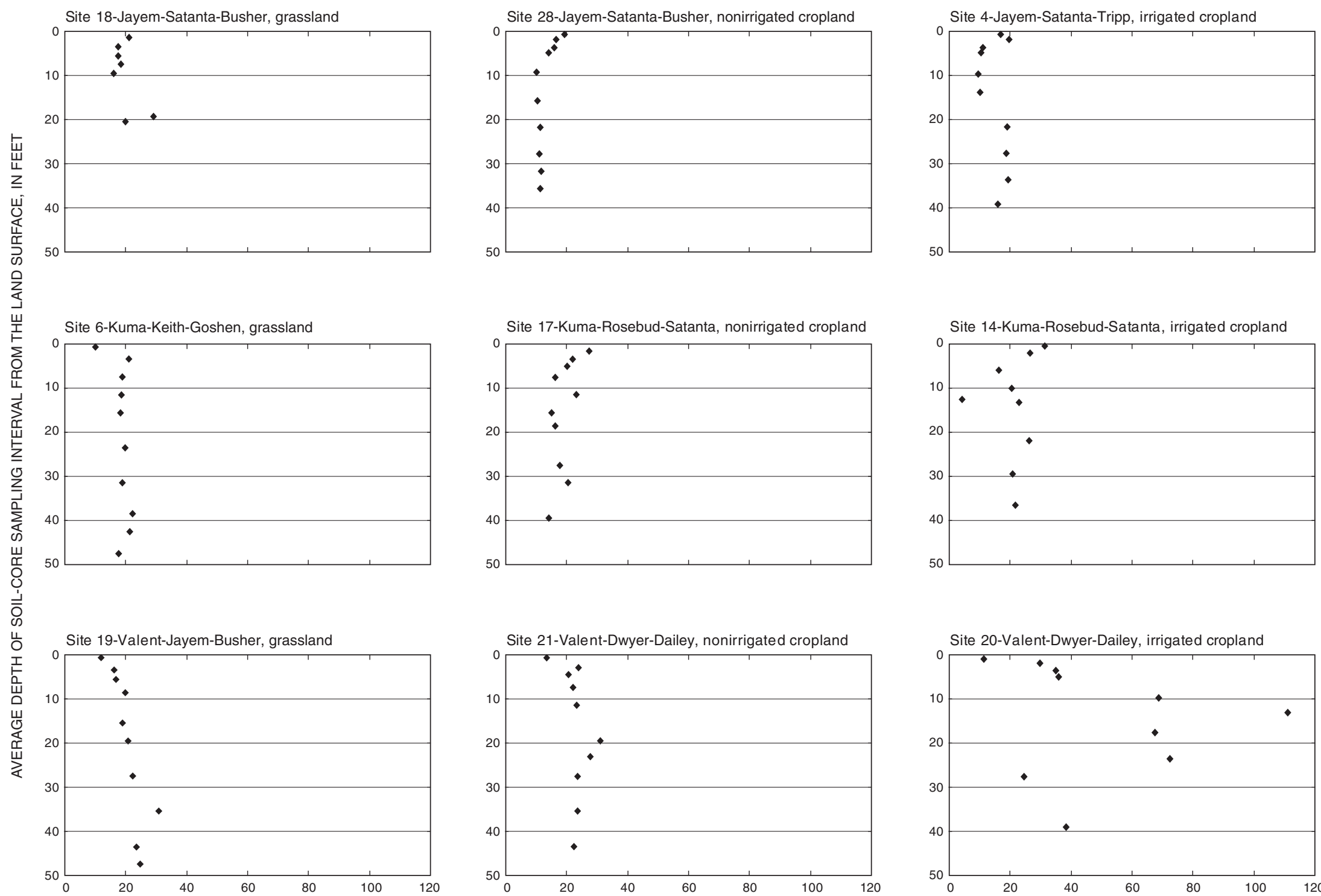

Site 17-Kuma-Rosebud-Satanta, nonirrigated cropland

Site 14-Kuma-Rosebud-Satanta, irrigated cropland
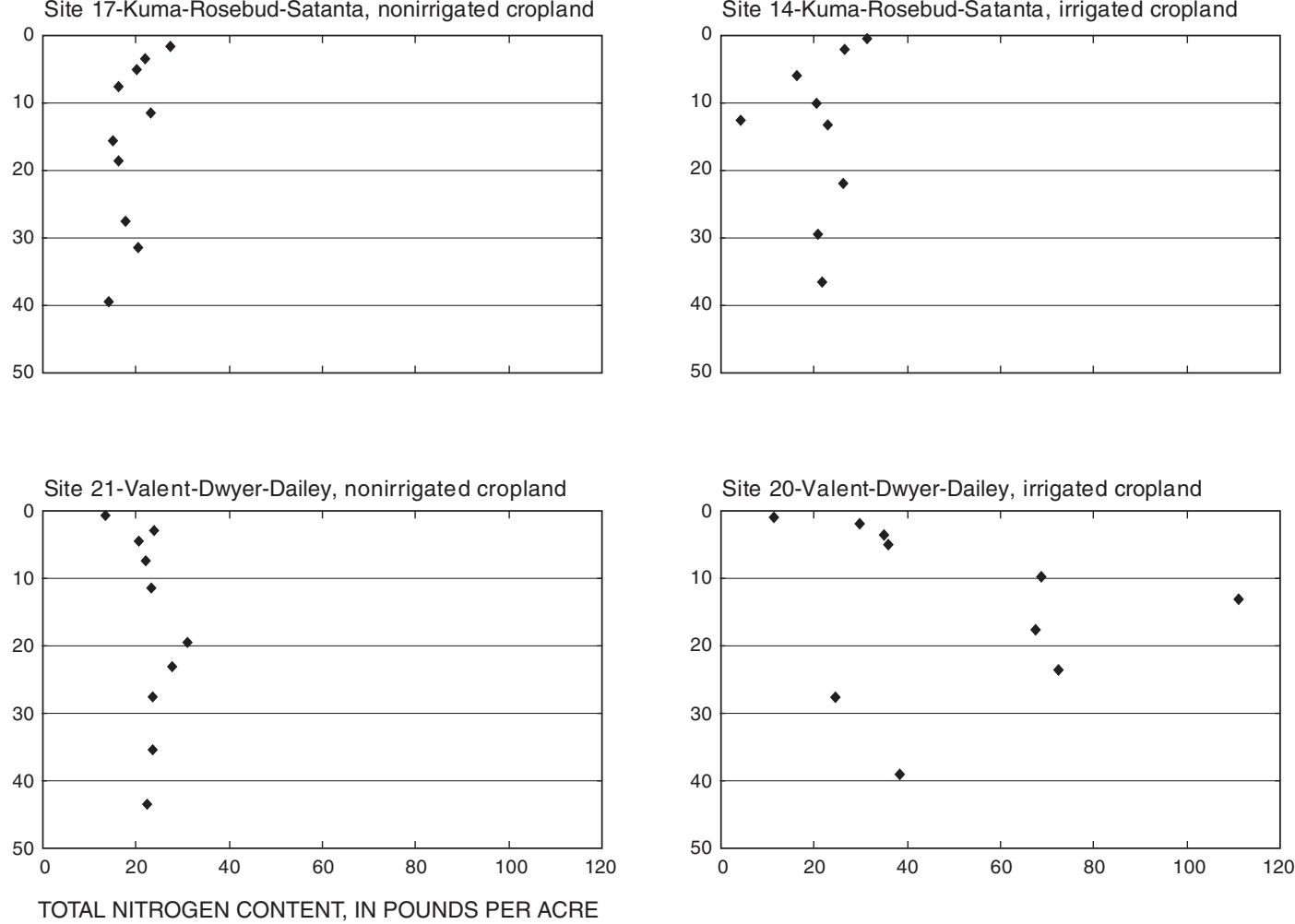

TOTAL NITROGEN CONTENT, IN POUNDS PER ACR

Figure 10. Nitrogen content in soil-core samples by depth, land use, and soil type, Upper Republican Natural Resources District, 1988-99. 
nitrate concentrations were higher than in $1998-3.5 \mathrm{mg} / \mathrm{L}$ in 1999 and $4.6 \mathrm{mg} / \mathrm{L}$ in 2001. Similarly, the focus on sampling in areas with elevated nitrate concentrations resulted in a higher median nitrate concentration $(4.5 \mathrm{mg} / \mathrm{L})$ for irrigation wells in 2000 than in 1998 (2.5 mg/L) or 1999 (2.6 mg/L).

Areas with nitrate concentrations exceeding $6 \mathrm{mg} / \mathrm{L}$, the URNRD's ground-water management-plan action level, generally were in north-central Chase, western and south-central Dundy, and south-central Perkins Counties. These areas correspond with upland areas with sandy and sandy/loamy soil with soil permeabilities ranging from 6 to $20 \mathrm{in} / \mathrm{hr}$, and a high percentage of cropland.

Although numerous compounds were included in the pesticide analyses of domestic- and irrigation-wells samples, only the organonitrogen (triazine) herbicides - acetochlor, alachlor, atrazine, metolachlor, prometon, propachlor, propazine, and trifluralin — and the atrazine degradation product, deethylatrazine, were detected. Atrazine and deethylatrazine were detected the most frequently.

Ground water collected from 8 of the 25 samples analyzed for the presence of tritium in 2000 had tritium levels below the method detection limit of $0.8 \mathrm{TU}$, indicating that water in these wells entered the system prior to 1952 . Because agricultural practices in the area increased in the 1950s and 1960s, it can be assumed that this water was not influenced by agricultural chemicals. This assumption is supported by nitrate concentrations measured in samples from these wells. The median nitrate concentration from samples with no detectable amount of tritium was $3.0 \mathrm{mg} / \mathrm{L}$, which is approximately the level of nitrate thought to occur naturally in ground-water systems in the area. Samples from wells with detectable concentrations of tritium had elevated concentrations of nitrate, ranging from 3.6 to $12 \mathrm{mg} / \mathrm{L}$ (median $=7.0 \mathrm{mg} / \mathrm{L}$ ).

Results from nitrogen-isotope speciation analyses for samples from three irrigation wells indicate that the source of nitrate in the ground water likely is synthetic fertilizer based on the $\delta^{15} \mathrm{~N}$ values, which were less than 2.0 per mil. At most sites, however, the source probably is either naturally occurring or a mixture of water from various anthropogenic sources (such as synthetic fertilizer and animal waste). Although $\delta^{15} \mathrm{~N}$ values in samples from three wells approached 10 per mil, which is the minimum value for an animal-waste source, none exceeded it. The likely nitrogen source in samples from these wells is a mix of fertilizers and animal waste, with possibly a greater influence from animal waste. It should be noted that denitrification of nitrogen from synthetic fertilizer can yield $\delta^{15} \mathrm{~N}$ values that are indistinguishable from animal waste. Because of the shallow depth to water, low dissolved-oxygen concentrations, and likely presence of organic material, it is possible that some of the water pumped by one well had undergone denitrification resulting in a slightly higher $\delta^{15} \mathrm{~N}$ value.

Nitrogen content in soil varied among and within all 29 soil-coring sites. In general, land used as rangeland or nonirrigated cropland had lower total nitrogen content throughout the soil core with an increase in nitrogen content in the deeper soil-core samples. Although soil-core samples collected from areas with irrigated cropland had similar characteristics, the concentrations measured were more variable than those from either rangeland or nonirrigated cropland with a higher nitrogen content generally found throughout the sample. Statistical comparisons of the mean total nitrogen content of the cores also indicated that the differences in nitrogen content in soil were related to land use ( $\mathrm{p}$-value $=0.03$ ). The nitrogen content measured in samples collected in areas of irrigated cropland was significantly higher than those measured in nonirrigated cropland areas ( $\mathrm{p}$-value $=0.01$ ). The increase in total nitrogen content with depth, and the elevated mean total nitrogen content in samples collected from areas of irrigated cropland, may be indications that nitrogen was carried beyond the root zone of plants by infiltration of irrigation water.

\section{References}

Adams, C.D., and Thurman, E.M., 1991, Formation and transport of deethylatrazine in the soil and vadose zone: Journal of Environmental Quality, v. 20, no. 3, p. 540-547.

Briel, L.I., 1993, Documentation of a multiple-technique computer program for plotting major-ion composition of natural waters: U.S. Geological Survey Open-File Report 93-74, 88 p.

Bureau of Reclamation, 1974, Appraisal report, supplemental water supply study, Frenchman-Cambridge Division, Nebraska: McCook, Nebr., Bureau of Reclamation, Kansas River Projects draft report, 109 p.

Cardwell, W.D.E., and Jenkins, E.D., 1963, Ground-water geology and pump irrigation in Frenchman Creek Basin above Palisade, Nebraska, with a section on The chemical quality of the water, by E.R. Jochens and R.A. Krieger: U.S. Geological Survey Water-Supply Paper 1577, 472 p.

Comfort, S.D., and Roeth, F.W., 1996, Atrazine: University of Nebraska, Institute of Agriculture and Natural Resources Bulletin G93-1158-A.

Dowdy, Shirley, and Wearden, Stanley, 1991, Statistics for research (2d ed.): New York, Wiley \& Co., Wiley Series in Probability and Mathematical Statistics, 629 p.

Drever, J.I., 1997, The geochemistry of natural waters (3d ed.): New Jersey, Prentice Hall, Inc., 436 p.

Engberg, R.A., and Druliner, A.D., 1988, Nebraska groundwater resources, in U.S. Geological Survey, National water summary 1986-Hydrologic events and ground-water resources: U.S. Geological Survey Water-Supply Paper 2325, p. 347-354.

Environmental Isotope Laboratory, 1998, Tritium analysis: Ontario, Canada, University of Waterloo, Department of Earth Sciences, Environmental Isotope Laboratory Technical Procedure 1.0, Rev. 4.0, Revised May 5, 1998, 27 p.

Fenneman, N.M., 1931, Physiography of the western United States: New York, McGraw-Hill, 534 p.

Fetter, C.W., 1988, Applied hydrogeology (2d ed.): Columbus, Ohio, Merrill Publishing Company, 592 p. 
Fishman, J.J., and Friedman, L.C., eds., 1989, Methods for determination of inorganic substances in water and fluvial sediments: U.S. Geological Survey Techniques of WaterResources Investigations, book 5, chap. A1, 545 p.

Follett, R.F., Keeny, D.R., and Cruse, R.M., eds., 1991, Managing nitrogen for groundwater quality and farm profitability: Madison, Wis., Soil Science Society of America, 357 p.

Heimes, F.J., Ferrigno, C.F., Gutentag, E.D., Luckey, R.R., Stephens, D.M., and Weeks, J.B., 1987, Comparison of irrigation pumpage with change in ground-water storage in the High Plains aquifer in Chase, Dundy, and Perkins Counties, Nebraska, 1975-83: U.S. Geological Survey WaterResources Investigations Report 87-4044, 34 p.

Helsel, D.R., and Hirsch, R.M., 1992, Statistical methods in water resources: Amsterdam, The Netherlands, Elsevier Science, Studies in Environmental Science, v. 49, 522 p.

Hem, J.D., 1985, Study and interpretation of the chemical characteristics of natural water: U.S. Geological Survey Water-Supply Paper 2254, 263 p.

Johnson, B., 2001, Center pivots nearly two-thirds of State's irrigated acres, NU inventory shows: Nebraska Institute of Agriculture and Natural Resources, NU IANR Newsletter, July 25, 2001.

Kendall, Carol, 1998, Tracing nitrogen sources and cycling in catchments, in Kendall, Carol, and McDonnell, J.J., eds., Isotope tracers in catchment hydrology: Amsterdam, Elsevier Science, p. 519-576.

Kendall, Carol, and Caldwell, E.A., 1998, Fundamentals of isotope geochemistry, in Kendall, Carol, and McDonnell, J.J., eds., Isotope tracers in catchment hydrology: Amsterdam, Elsevier Science, p. 51-86.

Lappala, E.G., 1976, Changes in the water supply in the Upper Republican Natural Resources District, southwest Nebraska, from 1952-75: U.S. Geological Survey Open-File Report 76-498, $17 \mathrm{p}$.

Lappala, E.G., 1978, Quantitative hydrogeology of the Upper Republican Natural Resources District, southwest Nebraska: U.S. Geological Survey Water-Resources Investigations Report 78-38, 200 p., 10 pl.

Madison, R.J., and Brunett, J.O., 1985, Overview of the occurrence of nitrate in ground water of the United States, in U.S. Geological Survey, National water summary 1988-Hydrologic events, selected water-quality trends, and ground-water resources: U.S. Geological Survey Water-Supply Paper 2275, p. 93-105.

Mathey, S.B., ed., 1990, Ground-water site inventory system, v. 2, chap. 4, in National water information system user's manual: U.S. Geological Survey Open-File Report 89-587, 288 p.

McMahon, P.B., 2001, Vertical gradients in water chemistry in the Central High Plains aquifer, southwestern Kansas and Oklahoma panhandle, 1999: U.S. Geological Survey WaterResources Investigations Report 01-4028, 47 p.

Nebraska Climate Office, 2003, Normals, means, and extremes for Nebraska: accessed October 30, 2003, at URL http://www.nebraskaclimateoffice.unl.edu/normals.htm
Nebraska Department of Natural Resources, 2002, Estimated water use in Nebraska, 1995: accessed April 23, 2002, at URL http://www.nrc.state.ne.us/otherresources/ waterreport95.html

Nowell, L.H., Capel, P.D., and Dileanis, P.D., 1999, Pesticides in stream sediment and aquatic biota-Distribution, trends, and governing factors: Boca Raton, Fla., CRC Press, Pesticides in the Hydrologic System Series, v. 4, 1,001 p.

Peckenpaugh, J.M., Kern, R.A., Dugan, J.T., and Kilpatrick, J.M., 1995, Simulated response of the High Plains aquifer to ground-water withdrawals in the Upper Republican Natural Resources District, Nebraska: U.S. Geological Survey Water-Resources Investigations Report 95-4014, 60 p.

Ponte, M., 2001, Configuration of water table (McCook Quadrangle): Conservation and Survey Division Water Survey Map GM-54.6, Conservation and Survey Division, Institute of Agricultural and Natural Resources, University of Nebraska-Lincoln, scale 1:250,000, 1 sheet.

Pritt, J.W., and Jones, B.E., eds., 1989, 1990 National Water Quality Services Catalog: U.S. Geological Survey Open-File Report 89-386, 132 p.

Sandstrom, M.W., Wydoski, D.S., Schroeder, M.P., Zamboni, J.L., and Foreman, W.T., 1992, Methods of analysis by the U.S. Geological Survey National Water Quality Laboratory-Determination of organonitrogen herbicides in water by solid-phase extraction and capillary-column gas chromatography/mass spectrometry with selected-ion monitoring: U.S. Geological Survey Open-File Report 91-519, 26 p.

Soil Conservation Service, 1963, Soil survey of Dundy County, Nebraska: U.S. Department of Agriculture, Soil Conservation Service, 89 p.

Soil Conservation Service, 1982, Soil survey of Chase County, Nebraska: U.S. Department of Agriculture, Soil Conservation Service, $187 \mathrm{p}$.

Soil Conservation Service, 1991, Soil survey of Perkins County, Nebraska: U.S. Department of Agriculture, Soil Conservation Service, 178 p.

Stanton, J.S., 2000, Distribution of nitrate in ground water in the Republican River Basin, southwest Nebraska, 1996-98: U.S. Geological Survey Water-Resources Investigations Report 00-4056, 6 p.

Starr, R.C., and Gillham, R.W., 1993, Denitrification and organic carbon availability in two aquifers: Ground Water, v. 31, no. 6, p. 934-947.

Steele, G.V., 1998, Nitrate and other water-quality characteristics, and nitrogen in the unsaturated zone, in the Red Willow and Hitchcock Counties Special Protection Area, southwest Nebraska, 1993-95: U.S. Geological Survey WaterResources Investigations Report 98-4138, 71 p.

Steele, G.V., 1999, Interaction of streams and ground water in selected tributaries of the Republican River, Nebraska, 199899: U.S. Geological Survey Water-Resources Investigations Report 99-4200, 6 p.

Strategic Diagnostic Inc., 1997a, Start-up manual for the RaPID assay system: Newark, Delaware, Strategic Diagnostic Inc., $22 \mathrm{p}$. 
Strategic Diagnostic Inc., 1997b, RaPID assay atrazine test kit: Newark, Delaware, Strategic Diagnostic Inc., 9 p.

U.S. Census Bureau, 2002, Your gateway to Census 2000: accessed December 23, 2002, at URL http://factfinder.census.gov/bf/_lang=en_name= DEC_2000_PL_U_GCTPL_ST7_geo_id=04000US31.html

U.S. Environmental Protection Agency, 1983, Methods for chemical analysis of water and wastes: U.S. Environmental Protection Agency, Office of Research and Development Report EPA/600/4/79/020, 552 p.

U.S. Environmental Protection Agency, 1993, Methods for the determination of inorganic substances in environmental samples: U.S. Environmental Protection Agency, Office of Research and Development Report EPA/600/R-93/100, 172 p.
U.S. Environmental Protection Agency, 2002, Drinking water regulations and health advisories: U.S. Environmental Protection Agency, Office of Ground Water and Drinking Water, EPA 816-F-02-013, accessed August 7, 2002, at URL http://www.epa.gov/safewater/mcl.html

Zaugg, S.D., Sandstrom, M.W., Smith, S.G., and Fehlberg, K.M., 1995, Methods of analysis by the U.S. Geological Survey National Water Quality Laboratory-Determination of pesticides in water by $\mathrm{C}$ - 18 solid-phase extraction and capillary-column gas chromatography/mass spectrometry with selected-ion monitoring: U.S. Geological Survey OpenFile Report 95-181, 60 p.

Zlotnik, Vitaly, Burbach, M.E., Exner, M.E., and Spalding, R.F., 1995, Well sampling for agrichemicals in large capacity systems: Journal of Soil and Water Conservation, v. 50, no. 1 , p. $95-101$. 